\title{
WP 24_10
}

\author{
Paolo Figini \\ University of Bologna and RCEA \\ Laura Vici \\ University of Bologna and RCEA
}

\section{OFF-SEASON TOURISTS AND THE Cultural OfFER OF A MASS-TOURISM DESTINATION: THE CASE OF RIMINI}

Copyright belongs to the author. Small sections of the text, not exceeding three paragraphs, can be used provided proper acknowledgement is given.

The Rimini Centre for Economic Analysis (RCEA) was established in March 2007. RCEA is a private, nonprofit organization dedicated to independent research in Applied and Theoretical Economics and related fields. RCEA organizes seminars and workshops, sponsors a general interest journal The Review of Economic Analysis, and organizes a biennial conference: The Rimini Conference in Economics and Finance (RCEF) . The RCEA has a Canadian branch: The Rimini Centre for Economic Analysis in Canada (RCEACanada). Scientific work contributed by the RCEA Scholars is published in the RCEA Working Papers and Professional Report series.

The views expressed in this paper are those of the authors. No responsibility for them should be attributed to the Rimini Centre for Economic Analysis. 


\title{
Off-season tourists and the cultural offer of a mass-tourism destination: the case of Rimini
}

\author{
Paolo Figini" and Laura Vici
}

\begin{abstract}
This paper assesses the potential implications on off-season tourism of enhancing the cultural offer of Rimini, a popular Italian seaside holiday destination. Rimini, a city of about 130,000 people hosts a total of around 12 million overnight stays, 10 million of which are concentrated in the summer months. In the last twenty years or so, Rimini has been undergoing a policy of deseasoning, which mainly pivots around business tourism (a new fair quarter and important conference venues have been built) and cultural tourism (the city has been investing on both its cultural heritage and art exhibitions).

This assessment is carried out through discrete choice experiments submitted to a sample of about 800 off-season tourists, that is, tourists who visited Rimini outside the summer months. Since tourism can be viewed as a composite good, which overall utility depends on the arrangement of the component characteristics, the choice experiments allow to disentangle the importance and the willingness to pay of tourists for different levels of the holiday's characteristics.

The choice model incorporates as attributes a number of possible changes to actual tourism features (which are also the subject of public debate), including them in hypothetical alternative "holiday packages". The conditional logit analysis of the choice experiments can highlight the potential synergies and trade-offs between cultural and business tourism. Moreover, the methodology and the structure of the questionnaire allow a partial comparison of our findings with results stemming from two previous studies carried out in Rimini, respectively on summer tourists and on residents. Such comparison highlights synergies and trade-offs between off-season tourists, summer tourists, and residents.
\end{abstract}

Keywords: tourism demand; cultural tourism; business tourism, conditional logit; urban planning; choice experiments.

\footnotetext{
* Corresponding author: Department of Economics, University of Bologna, Piazza Scaravilli 2, I-40126, Bologna, Italy. E-mail: paolo.figini@unibo.it. The authors thank Guido Candela for preliminary discussion on the structure of the questionnaire, the students of the master degree in Economics and Management of Tourism for carrying out the interviews and for preparing the dataset, and participants to the XVI ACEI Conference held in Copenhagen and to the III RCEF Conference held in Rimini. The usual disclaimers apply.
} 


\section{Off-season tourists and the cultural offer of a mass-tourism destination: the case of Rimini}

\section{Introduction}

Cultural tourism is an important topic, lying at the cornerstone of cultural and tourism economics and constituting the motivation for a vast and growing scientific production. However, these two fields of research rarely communicate one to each other. A brief, anecdotal analysis of the literature shows that articles published on journals of cultural economics rarely quote tourism economic journals and viceversa. This is partially due to the fact that, in the two literatures, the focus on cultural tourism has different motivations and approaches.

In tourism economics, cultural tourism is often recalled as the main tool used to counteract seasonality in destinations and to overcome problems related to the maturity stage of their life-cycle. For tourism destinations, in fact, seasonality is one of the main issues of concern, leading to many negative economic effects: ${ }^{1}$ i) the difficult identification of the optimal level of investment as regards the dimension of tourism structures (a problem of the long run); ii) the higher level of volatility (and risk) in the economic performance (which is higher the shorter the length of the "peak-seas on"), which drives to the search of high rates of return to the investment in the only "profitable" season; iv) the overload in terms of social and environmental carrying capacity of the destination. On the other hand, seasonality can also produce positive effects, if one thinks that the mass of tourists hosted by the destination in the peak-season might be the only possibility to finance the organization of costly and sophisticated cultural events.

Moreover, cultural tourism is often considered a viable policy option to implement when a mass-tourism destination reaches its maturity stage. Firstly, a mature destination lacks of competitiveness due to both the obsolescence of its structures and infrastructures and to the worsening of its price/quality ratio, which follows the development of its economy. Secondly, among the different types of tourism to invest in, cultural tourism is often considered the first best for a series of motivations, often recalled in policy discussions: i) cultural tourists have a higher propensity to spend and, in general, higher average income; ii) they spend away from homogeneous mass products, being more interested in local quality goods (restaurants, wine, shopping) and in cultural events (shows, concerts, exhibitions) with higher value added, and which benefits are more likely to be evenly spread within the destination; iii) they are mainly independent holiday makers, therefore less dependent on external tour operators and travel agencies. ${ }^{2}$

In cultural economics, on the other hand, tourism is considered a valuable sector, mainly for two reasons: firstly, it is the target market for the cultural offer of a territory, since the great majority of cultural sites' visitors are not resident; secondly, it brings into a territory the financial resources needed to invest in the conservation of the cultural heritage and in the development of new sites, exhibitions and innovative forms of art. It follows that, in cultural economics, the analysis of tourism is mainly focussed on applying evaluation methods (such as contingent valuation or travel costs) to tourists interviewed at cultural sites,

\footnotetext{
1 On the analysis of seasonality in tourism see, among others, Baum and Lundtrop (2001), Candela and Castellani (2008), Hylleberg (1992), Koenig-Lewis and Bishoff (2005), Rossellò Nadal et al. (2004).

2c However, the empirical evidence does not completely support this vision, and recent literature finds mixed evidence (Del Corpo et al, 2008): cultural tourists tend to choose shorter holidays, they rarely repeat visits (making fidelity more difficult to implement), and their daily expenditure is lower than other types of tourists (i.e., business tourists). The overall evaluation of investment strategies in cultural tourism, therefore, has to be destination-specific, not being a general panacea for tourism and economic development.
} 
in order to attach a value on the conservation of these sites and to provide guidelines to policy makers in order to decide how to allocate resources. ${ }^{3}$

Moreover, Caserta and Russo (2002) highlight that for heritage and cultural cities, the development of cultural mass tourism can lead to a growth of same-day visits, with a subsequent decrease in profits for secondary goods (i.e., accommodation and restaurants in the destination), a decrease in quality of the holiday, less resources available for cultural sites and an overall negative effect on the destination (see also Candela et al., 2003).

Consequently, although for partially different reasons, cities are interested in promoting cultural tourism. Art cities because it is the natural way to increase the value of their cultural heritage; tourism destinations because it is one of the main policies that can counteract the high seasonality induced by natural, social and cultural factors and the maturity stage of their life-cycle. These statements raise the following questions: can any city become a tourism destination? Can any tourism destination, particularly a mass tourism destination, succeed in a policy of diversification and investment in cultural tourism?

In this paper, we attempt to provide an answer to the second question by analysing one of the main Italian (and European) seaside resorts, Rimini, and leaving the analysis of art cities and of the impact of mass tourism on cultural heritage to other research. ${ }^{4}$

In particular, the paper assesses the potential implications on off-season tourism of enhancing the cultural (and leisure) offer of Rimini. Located on the Adriatic sea, Rimini is a middle-size city with about 130,000 inhabitants and an income per capita which is higher than the Italian average. Together with its province (mainly a linear city of about $40 \mathrm{Kms}$ of coast, including the municipalities of Bellaria, Riccione, Misano and Cattolica) it hosts a total of almost 16 million overnight stays (Table 1), half of which are concentrated in the main city of Rimini.

Although tourism represents one of the main economic sectors of the city, Rimini is now a destination in the mature stage of its development, and has been undergoing a strong economic diversification (mainly in the manufacturing sector) and has been investing in the promotion of forms of tourism that uses the territory outside the summer season. In fact, in the last twenty years or so, Rimini has been tackling the problem of seasonality through a restyling policy which mainly pivots around business and cultural tourism. ${ }^{5}$ As regards business tourism, a new fair quarter has recently been developed North of Rimini, in a strategic position, since it is close to the motorway and to the railroad. The opening of a new train station in front of the main entrance of the fair quarter allows visitors to travel to Bologna in one hour and to Milan in about two hours, driving Rimini fair to become the third pole in Italy. Moreover, important conference venues have been built in the last few years. With respect to cultural tourism, the city has Roman origins and hosts an important cultural heritage. In recent years many investments have been carried out in the promotion of its cultural heritage (as the "Domus del Chirurgo") and in art exhibitions.

Indeed, Rimini constitutes an important case-study in order to assess whether sinergies and trade-offs between different types of tourists visiting the destination off the main (summer) season exist. In such a way, one could possibly evaluate the effectiveness and the efficiency of policies aimed at promoting business and cultural tourism in a city which is organized to be a "leisure" mass-tourism destination.

3 Among others, see Alberini and Longo, 2006; Navrud and Ready, 2002; Poor and Smith, 2004.

4 A methodologically consistent comparison between a holiday destination (diversifying in cultural tourism) and a cultural site (investing in tourism structures) could lead to interesting considerations about analogies and differences with respect to cultural and tourism policies.

5 Although seasonality is still strong, it is constantly decreasing: the share of overnight stays in the summer season (June - September) was 82\% in 1999 and "only" 76\% in 2007. 
Table 1. Arrivals, Overnight stays and Length of Stay of Italian and Foreign Tourists in the province of Rimini (1972 - 2007, thousands).

\begin{tabular}{|c|c|c|c|c|c|c|c|c|c|}
\hline Year & $\begin{array}{c}\text { Arrivals, } \\
\text { Italians }\end{array}$ & $\begin{array}{c}\text { Arrivals, } \\
\text { Foreigners }\end{array}$ & $\begin{array}{c}\text { Arrivals, } \\
\text { Total }\end{array}$ & $\begin{array}{l}\text { Overnight } \\
\text { stays, } \\
\text { Italians }\end{array}$ & $\begin{array}{l}\text { Overnight } \\
\text { stays, } \\
\text { Foreigners }\end{array}$ & $\begin{array}{c}\text { Overnight } \\
\text { stays, Total }\end{array}$ & $\begin{array}{c}\text { Length of } \\
\text { stay, Italians }\end{array}$ & $\begin{array}{c}\text { Length of } \\
\text { stay, } \\
\text { Foreigners }\end{array}$ & $\begin{array}{l}\text { Length of } \\
\text { stay, Total }\end{array}$ \\
\hline 1972 & 630 & 399 & 1029 & 10274 & 5407 & 15680 & 16,31 & 13,55 & 15,24 \\
\hline 1977 & 733 & 410 & 1143 & 10408 & 5183 & 15592 & 14,20 & 12,64 & 13,64 \\
\hline 1982 & 1146 & 589 & 1734 & 11906 & 6154 & 18060 & 10,39 & 10,45 & 10,42 \\
\hline 1987 & 1477 & 660 & 2137 & 11809 & 5816 & 17624 & 8 & 8,81 & 8,25 \\
\hline 1992 & 1812 & 415 & 2227 & 12624 & 2935 & 15559 & 6,97 & 7,07 & 6,99 \\
\hline 1997 & 1828 & 528 & 2355 & 11813 & 3646 & 15459 & 6,46 & 6,91 & 6,56 \\
\hline 2002 & 2089 & 586 & 2675 & 12034 & 3661 & 15695 & 5,76 & 6,25 & 5,87 \\
\hline 2007 & 2335 & 613 & 2948 & 12200 & 3522 & 15722 & 5,22 & 5,75 & 5,33 \\
\hline
\end{tabular}

Source: Statistical Office, Province of Rimini

The research was carried out through discrete choice experiments submitted to a sample of about 800 "off-season" tourists, that is, tourists who visited Rimini outside the summer months (interviews were conducted during the months of April and May 2010). Choice experiments are a survey-based technique often used to place a value on a non-marketable or semi-public good, and allow to evaluate the relative weight of different attributes of a holiday.

Its use has spread in many research fields (marketing, health, transport and environmental economics) and in recent years it has often been applied in tourism economics to analyse tourists' preferences with respect to trip attributes, recreational and heritage demand, the attractiveness of a destination and tourism policies. ${ }^{6}$ Its use is not so common in cultural economics, in which other types of stated preferences approaches are often applied. ${ }^{7}$

Since the holiday can be viewed as a composite good, which overall utility depends on the arrangement of the component characteristics, the choice experiments allow to disentangle the importance and the willingness to pay of tourists for different levels of their holiday's characteristics. In particular, we aimed to detect the effect of changes in the intensity (levels) of six key characteristics (attributes) that identify the use of Rimini's territory (and which are also the subject of public debate). Our paper focusses on the preferences of "secondary types" of tourists regarding possible and hypothetical modifications in the urban, territorial and cultural configuration of their stay in Rimini. ${ }^{8}$ Interviews to a representative sample of business and cultural tourism were conducted in Spring 2010 to estimate the willingness to pay (WTP) for (hypothetical) changes in the composition of the tourism product. Conditional logit models enabled us to estimate the relative weight of each attribute in affecting the tourists' choice and allowed us to indicate the potential synergies and trade-offs between cultural, business and leisure tourism.

It is important to highlight that the methodology used and the structure of the questionnaire allowed us a partial comparison between our findings and the results stemming from two previous studies carried out in Rimini, respectively on summer tourists (Brau et al., 2009) and on residents (Figini et al., 2009). This might highlight potential synergies and trade-offs between the preferences of off-season tourists, summer

6 Among the many papers that recently used this methodology in tourism economics, see Apostolakis and Shabbar (2005), Brau and Cao (2008), Brau et al. (2009), Breffle and Morey (2000), Crouch and Louviere (2004), Figini et al. (2009), Huybers and Bennett (2000), Huybers (2005), Morey et al. (2002) and Papatheodorou (2001).

7 For an overview of the main differences among alternative stated preference methodologies, particularly with respect to contingent valuation, see Bateman et al. (2002), Bennet and Blamey (2001), Louvière et al. (2000), and Mazzanti (2003).

8 Recent papers on tourists' preferences in Rimini are Brau et al. (2009), Candela et al. (2007), Figini and Troia (2006), and Scorcu and Vici (2008). 
tourists, and residents, bringing to a comprehensive overview of the policy implications of implementing alternative strategies of tourism and cultural development.

With respect to summer tourists, synergies might stem from: i) the joint use of sophisticated tourism structures and attractions, which are economically sustainable only because a "peak-season" exists; ii) being tourism an experience good, the perceived level of quality in one season might have positive externalities in the intermediate season. On the other hand, trade-offs with summer tourism might stem from: i) the feeling of neglect and sadness, which is usually experienced by an off-season tourist when hosted in structures dimensioned on the peak-season; ii) the lack of offer or its inadequacy, when all the tourism sector is organized only for the peak-season.

With respect to local residents, their attitudes towards tourists should be carefully taken into consideration. The success of many tourism development programs depends on a local management that is sensitive both to the social impact of tourism on the host population, and able to increase the benefits derived from tourism, by preventing or reducing its negative aspects, also in relations with the mix of the different types of tourism. In particular, the possible trade-off with the local population stems from the fact that the most important resource for tourism - the environment or, more generally, the territory - is to be shared with residents. ${ }^{9}$

The remaining of the paper is structured as follows: in Section 2 we briefly review the methodology applied and describe the questionnaire. Section 3 illustrates some descriptive statistics of the survey. Section 4 presents the main econometric results of the choice experiments while Section 5 discusses the policy implications, also through a comparison with the results of previous studies on residents and summer tourists in Rimini. Section 6 discusses and concludes.

\section{The methodology and the survey}

The choice modelling is a stated-preference approach which investigates individual behaviour and estimates the value of goods (or projects) by asking people to choose among scenarios which differ for the combination of alternative levels of some selected attributes (characteristics). One of the advantages of choice experiments lies in their ability to model individuals' hypothetical demand for non-market goods. This enables analysts to elicit individuals' willingness to pay for goods and services that may otherwise be unattainable from observing actual behaviours. This methodology develops through three main steps (Hanley et al. 2001; Mazzanti 2003): i) identification of the basic characteristics (attributes) of the good or project to be evaluated, and their levels; ii) each respondent has to choose among alternative hypothetical scenarios characterized by different combinations of attributes' levels; iii) the econometric analysis of respondents' choices allows to estimate the relative importance of the attributes and, if a monetary factor or a price is included as attribute, the willingness to pay for different levels of an attribute.

Consistently with the random utility theory (Thurstone 1927; McFadden 1974), consumers' utility is considered a latent structure that cannot be observed directly. By designing and implementing a valid preference elicitation procedure, a significant proportion of the unobservable consumer utility can be

\footnotetext{
9 In the last 15 years, the socio-economic impact of tourism and the factors affecting residents' attitudes towards tourism in host communities have received some attention (Alberini et al., 2005; Akis et al., 1996; Crotts and Holland, 1993; Faulkner and Tideswell, 1997; Haralambopoulos and Pizam, 1996; Lindberg et al., 1997a, 1997b, 1999). In particular, tourism impact is often disaggregated into three categories: economic, socio-cultural and environmental effects (Ryan, 1991; Williams, 1979). Since tourism generally disrupts social, cultural and environmental local systems, the non-economic impact often tends to be negative as a whole (Liu et al, 1987), whilst economic effects are perceived as positive.
} 
assessed. The chosen scenario in each experiment corresponds, ceteris paribus, to the combination of attribute levels bringing the highest utility. ${ }^{10}$

Formally, given a sample of $H$ respondents, with $h=1,2, \ldots, H$, and a set of alternative choices, $j=1,2, \ldots, J$, the random utility specification can be represented as a linear additive specification with independently and identically distributed (IID) random terms (Louvière et al. 2000): ${ }^{11}$

$$
U_{h j}=\beta^{\prime} x_{h j}+\varepsilon_{h j} .
$$

where the unobservable utility value for the choice alternative $j$ made by consumer $h$ is given by a deterministic and systematic component and a random term, $\varepsilon_{h j}$.

In model (2.1), the probability that an individual $h$ picks alternative $i$ out of $J$ alternatives, can be represented as follows:

$$
P\left[y_{h}=i\right]=\frac{\exp \left(\mu \beta^{\prime} x_{i}^{h}\right)}{\sum_{j=1}^{J} \exp \left(\mu \beta^{\prime} x_{j}^{h}\right)}
$$

where $y_{h}$ is a choice index, representing the choice made by individual $h$, and $\mu$ is a scale parameter that typically assumes value 1 (Ben-Akiva and Lerman 1985) ${ }^{12}$ Moreover, the estimation of equation (2.1) with a conditional logit model, yields $\beta$ coefficients allowing to evaluate the rate at which respondents are willing to trade-off one attribute to another. This rate of substitution $\sigma$ is calculated as the ratio between the $\beta$ coefficients of two attributes. When attributes are discrete variables, the substitute ratio $\sigma$ is computed as "values of level change", as in (2.3). ${ }^{13}$

$$
\sigma=1-\frac{\beta^{i} \Delta x_{i}}{\beta_{s}}
$$

Specifically, in this paper we considered six attributes (and their levels), which are carefully described in Table 2 and define the alternative scenarios. ${ }^{14}$ The questionnaire was designed to gather information on off-season tourists perception of actual or hypothetical "holiday packages" offered by the territory of Rimini for leisure and cultural activities. Direct interviews to a sample of about 800 tourists were conducted in April and May 2010.

There are several reasons why these attributes were selected. Firstly, we had to consider important features of Rimini as regards potential interactions among off-season tourists, summer tourists and residents (trade-off and synergies) in the use of the territory and in terms of actual political debate. This reason motivated the inclusion in the survey of the attributes of organized system of wellness and sport facilities (attribute n. 3) and the commercial offer (attribute n. 5), since the underlying rationale is to offer

10 Lancaster's hedonic theory $(1966,1971)$, which states that goods are not demanded per se, but for their elementary characteristics, can be considered the theoretical foundation of discrete choice models.

11 The IID assumption entails the property of independence of irrelevant alternative (IIA - McFadden 1984). Violations of the IIA assumption may arise when some alternatives are qualitatively similar to others or when there are heterogeneous preferences among respondents.

12 The scale factor $\mu$ is inversely proportional to the standard deviation of the error distribution. Assuming $\mu$ equal to 1 implies a constant error variance.

${ }_{13}$ When the attribute is expressed in monetary terms, this trade-off $\sigma$ is an "implicit price". These estimates rely on the assumption that the marginal utility of income is constant: this holds only when small changes are considered (involving a tiny share of total individual income).

14 The identification of the six attributes and their levels was the result of frequent research meetings, also with local stakeholders; a pilot test was carried out in the weeks preceding the survey and proved very useful to check the comprehension of the attributes and the clear perception of the difference in levels. 
structures that are already available in the territory, but that are used under their full capacity outside the summer season.

Secondly, sustainability considerations and policies aimed at protecting and developing natural and cultural resources are common features of contemporary policy agendas. Rimini is a mass tourism destination, but also a middle-size city, and tourists' willingness to pay for a more environmentally friendly city might play a crucial role both in the policy strategy, and in terms of tourism development. This reason motivated the inclusion in the survey of the attributes of environmental protection of the beach (attribute n. 2), the organization of day-trips in the surroundings of Rimini (attribute n. 1) and the promotion of cultural and leisure activities through particular cards (attribute n. 4). ${ }^{15}$

Finally, the cost attribute included in the survey was identified with time (attribute n. 6): we were inquiring whether the tourists, given the other attribute levels of the scenario, were willing to stay (and pay for) one night or two nights more (and take one day off from work). The decision of considering a time cost, and not a monetary value, was mainly driven by the fact that an important part of off-season tourists interviewed were business tourists, whose trip was organized and payed by their employer. To provide a price attribute to them therefore would have been highly hypothetical, since the trip budget was not fully under their control. Moreover, we were observing a high heterogeneity in both incomes and in the cost of accommodation, which would not fit with the crucial assumption of constant marginal utility, which is implied by model 2.1 and by the assumption of IIA. On the contrary, time seemed to be more binding for off-season tourists, since the intermediate season is not the time for yearly holidays and tourists would have to ask one or more days off from work to widen their stay. Moreover, from the destination point of view, the decreasing average length of stay, which is one of the main features of contemporary tourism, ${ }^{16}$ can lead to a deterioration of the overall quality of its tourism product, with negative consequences on the destination's reputation, which can drive it into a vicious circle (Candela et $a l ., 2003)$. Therefore, it can be argued that the relevant variable to target, for tourism destinations, is not overall tourists spending, but the length of stay in the destination (which, however, is directly linked to spending).

15 The attributes and their respective levels were very similar to the ones submitted to summer tourists (Brau et al. 2009) and to residents (Figini et al. 2009) in two parallel surveys. Although some differences exist, particularly on the monetary and the cultural attributes, this allowed us to compare, at least partially, the elicited preferences of tourists and residents over the shared territory of Rimini (see Section 5).

16 Table 1 shows that the average length of stay in Rimini went down from 15 days in 1972 to 10 days in 1982 , to little more than 5 days in 2007. 
Table 2. Definition of attributes and their levels

Attribute 1 - Organization of social events and availability of one-day trips in the surroundings of Rimini

Level 1 (status quo): one-day trips are always available if self-organized, with no tourist guide.

Level 2 (organized trips): at the hotel it is possible to organise and book guided tours in the surroundings of Rimini.

\section{Attribute 2 - Environmental impact of bathing establishments and other beach services}

Level 1 (high preservation of beach environment): The environmental impact of bathing establishments and other beach services, bars and restaurants is low (rare and small concrete buildings) and the seaside avenue is closed to traffic.

Level 2 (medium preservation of beach environment): The environmental impact of bathing establishments and other beach services, bars and restaurants is low (rare and small concrete buildings) and the seaside avenue is open to traffic.

Level 3 (medium preservation of beach environment): there is a high number of permanent buildings (in concrete) for bathing establishments and other beach services and the seaside avenue is closed to traffic.

Level 4 (low preservation of beach environment - status quo): there is a high number of permanent buildings (in concrete) for bathing establishments and other beach services and the seaside avenue is open to traffic.

Attribute 3 - Health, Sport and Wellness tourism

Level 1 (wellness and sport events are not organized - status quo): it is possible to avail of wellness structures and sport activities in detached facilities (or in some hotels), after paying a separate ticket.

Level 2 (integrated system of sport and wellness facilities): it is possible to avail of integrated wellness structures and sport activities, included in the price of the hotel.

Attribute 4 - Cultural and Leisure activities offered off-season in Rimini.

Level 1 (status quo): the city offers a few museums and a good level of heritage conservation, opened day-time.

Level 2 (cultural card): the hotel package includes a card allowing tourists to visit the main museums, heritage and exhibitions.

Level 3 (leisure card): the hotel package includes a card allowing tourists to enter or to have discounts in some bars, restaurants and night clubs.

Level 4 (all inclusive cultural and leisure card): the hotel package includes a card allowing tourists to visit the main museums, heritage and exhibitions and allowing them to enter or to have discounts in some bars, restaurants and night clubs.

Attribute 5 - Evening and night opening of shops

Level 1 (closed shops - status quo): in the city centre and on the seaside, shops are usually closed at late evening, night and on Sundays (exceptions are the few commercial malls outside the city (Malatesta, Befane).

Level 2 (night opening of shops): in the city centre and on the seaside, shops are systematically opened at late evening, night and on Sundays according to the needs of off-season tourists.

Attribute 6 - Time cost of the scenario: willingness to spend more time in Rimini. Level 1 ( 0 extra-night spent in Rimini): given the present scenario, there is no willingness to stay one more day at own expenses.

Level 2 (1 extra-night spent in Rimini): given the present scenario, there is willingness to stay one more day at own expenses.

Level 3 (1 extra-night and one day of leave from work): given the present scenario, there is willingness to stay one more day at own expenses and take one day off work.

Level 4 (2 extra-nights and one day leave from work): given the present scenario, there is willingness to stay two more days at own expenses, and take one day off work. 
The full factorial of all the possible combinations of attribute levels would yield, in our case, 512 scenarios. An orthogonal fractional factorial design was used to reduce the number of profiles at a convenient size: 32 scenarios were identified. Pair-wise comparisons were created using the shifted design strategy (Louviere et al. 2000). The interviews were hence split into four groups whose respondents had to answer to different sets of 8 choice cards with different pairs of hypothetical alternative scenarios. ${ }^{17} \mathrm{We}$ explicitly did consider a status quo alternative, asking the respondents whether they would prefer it irrespectively of the chosen alternative. ${ }^{18}$

Overall, the survey was divided into six sections: ${ }^{19}$ the first section collected the main coordinates of the interview (date, location and length); the second part inquired into the socio-economic and demographic characteristics of the respondent and his/her household; the third section inquired into the main coordinates of the holiday (main motivation of the trip, way of booking, length of stay, etc.); the fourth section was the choice experiments and asked to choose among eight pairs of alternative scenarios; the fifth section inquired into the self-evaluation of the characteristics under investigation given by the respondent, while the sixth section brought together some other information about the comprehension of the experiment. In particular, the interviewer annotated the degree of comprehension, interest and facility both in answering questions and in choosing the alternatives. Problems of poor identification of alternative scenarios were somehow relevant: the reported level of comprehension of the choice experiment was not satisfying overall $(13,2 \%$ of the sample did not understand properly the questionnaire according to the interviewers' impressions). Given the high number of interviews, we decided to exclude from the analysis all those observations for which the level of comprehension, the interest and the facility of choice was reported insufficient and the ones with incoherent answers. This let us with a sample of 718 questionnaires (out of 825). Interviews took on average 15 minutes.

\section{Tourists' demographic and social characteristics}

Since data on the characteristics of off-season tourists in Rimini are not available (apart from a breakthrough between Italians and Foreigners), interviews were conducted randomly in different places (trade fair quarter, museums, streets, train station, airport, hotels), in a period (April and May) in which Rimini is visited by both cultural and business tourists and in which the city has been investing in the last two decades in order to de-seasonalize tourism activities. The distribution of respondents' characteristics provides the following statistics, that are described in Table 3.

Firstly, as regards the region of origin, $88.4 \%$ of respondents were Italians (among which, $41.6 \%$ came from Northern Italy, $28.5 \%$ from Central Italy, and $29.9 \%$ from Southern Italy) and $11.6 \%$ were Foreigners. Males were $57.2 \%$ and females $43.8 \%$ of the sample. The $54.2 \%$ of the respondents were married or living with a stable partner, the remaining $45.8 \%$ were single.

Secondly, as regards the educational background, we found that $15 \%$ of the respondents hold a primary degree, $44.3 \%$ a secondary degree, while $40.7 \%$ a University degree. The high percentage of people holding a tertiary degree (differently from the Italian average) matched with the professional status of the respondents (among which we found $6.6 \%$ of entrepreneurs, $15 \%$ of professionals, $4.2 \%$ of managers,

\footnotetext{
${ }_{17}$ The pilot test showed that respondents could cope with up to eight choice pairs each. In fact, violations related to instability of preferences can arise from learning and fatigue effects (Hanley et al. 2002). In order to make clear and homogeneous the comprehension of attributes and to facilitate the individual decision process, the oral explanation of these attributes and levels was accompanied by the presentation of drawings and photos describing each scenario. In each group, the cards submitted were the same but presented every time with a different sequence, in order to avoid any question order bias.

18 The explicit definition of the status quo allows for a more coherent evaluation of the proposed scenarios. In our case, only $3.2 \%$ of the stated preferences were not confirmed after the comparison with the status quo.

19 The questionnaire (in Italian) is available from the authors upon request.
} 
$29.4 \%$ of employees / white collars) and with the general characteristics of both cultural and business tourists.

Thirdly, as regards income, it is not uncommon in this type of surveys to find a fairly important percentage of non respondents ( $10.2 \%$ in our case); however, the reported distribution of net monthly household income is likely to be true.

Finally, we asked whether the respondents were members of environmental $(8.4 \%)$ cultural $(27 \%)$ or sport (32\%, including gym and fitness clubs) associations. This information has provided useful for some of the robustness analysis carried out to test the econometric model.

Table 3. Demographic and socio-economic characteristics of the sample

\begin{tabular}{lcll}
\hline & & & \\
\hline Age class & $\%$ & $\begin{array}{l}\text { Occupational / professional } \\
\text { status }\end{array}$ & $\%$ \\
$<30$ & $24.2 \%$ & Entrepreneur & $6.6 \%$ \\
$30-39$ & $22.6 \%$ & Professional & $15.0 \%$ \\
$40-49$ & $19.1 \%$ & Craftsman & $3.1 \%$ \\
$50-59$ & $19.6 \%$ & Manager & $4.2 \%$ \\
$\geq 60$ & $14.5 \%$ & Dealer & $5.2 \%$ \\
& & Employee / white collar & $29.4 \%$ \\
Income class (Euro) & & Worker / blue collar & $4.9 \%$ \\
$($ net month family income) & & Teacher & $6.7 \%$ \\
$<1000$ & $10.5 \%$ & Farmer & $0.3 \%$ \\
$1001-2000$ & $35.1 \%$ & Student & $12.7 \%$ \\
$2001-3000$ & $25.4 \%$ & Retired & $8.9 \%$ \\
$3001-4500$ & $17.6 \%$ & Other & $3.2 \%$ \\
$4501-6000$ & $7.6 \%$ & & \\
$6001-10000$ & $2.1 \%$ & Gender & $57.2 \%$ \\
$>10000$ & $1.7 \%$ & Males & $42.8 \%$ \\
\hline
\end{tabular}

The second part of the questionnaire inquired into the characteristics of the trip / holiday in Rimini (Table 4).$^{20}$ Firstly, we asked what was the main motivation of the holiday. We found that the sample could be divided into three main sub-samples: business tourists (42.6\%), cultural tourists $(21.6 \%)$, and leisure tourists $(34.5 \%){ }^{21}$

Secondly, the $59.5 \%$ of the sample self-organized the trip, $15.9 \%$ directly asked to a travel agency / tour operator to organize it, while the remaining $24.6 \%$ let the own company to take care of all the bookings. This aspect often interacts with the responsibility of payment. We found that $69,5 \%$ of people directly paid the trip, only $26.5 \%$ had the trip payed (or refunded) by their own company, while the remaining $4 \%$ was invited. It is therefore interesting to notice that an important share of people traveling for business reasons directly paid the price of the trip (42.5\%). Finally, almost all business travelers $(89.5 \%)$ let the company organize the trip (even through a tour operator), although there is a relevant share $(10.5 \%)$ who self-organized it. Moreover, $54.5 \%$ of the sample used Internet to gather information, organize and/or buy different services, while the $30 \%$ did not use it (the remaining $15.5 \%$ did not know, probably because the trip was organized by someone else).

20 It is worth to report that not all the tourists stayed in the main city of Rimini: a small percentage (4.7\%) of the sample stayed in one of the towns surrounding the Rimini municipality.

$21.3 \%$ of the sample reported "other reasons". It is curios to report the experience of a tourist who, compelled to remain in Italy in the days of the Eyjafjallajökull eruption in Iceland, decided to spend a few days in Rimini. 
As regards the mean of transportation, car was the most important (45\%), followed by train (26.9\%), airplane (14.9\% - although $8.4 \%$ have used another mean - train, bus or car to finally reach Rimini), bus (13\%), boat $(0.3 \%)$.

As regards accommodation, as expected, the great majority of tourists stayed in three-star hotels (47.8\%) and four/five-star hotels (39.4\%). Among other accommodations, it is noticeable that the 5\% of tourists was hosted by friends and relatives. Among the respondents who stayed in hotels, $60.5 \%$ decided for bed $\&$ breakfast service, while $18.1 \%$ opted for half-board and $12.7 \%$ for full-board treatment. The remaining $8.7 \%$ did not choose any boarding.

Another interesting aspect is related to the length of stay. As expected, off the summer season, the average length of stay is low (3.24 days), with $68.5 \%$ of the respondents who stayed up to three days (42.5\% up to two days). On the upper side of this distribution, it is to highlight that $3.1 \%$ of the sample stayed over one week (up to a maximum of 15 days).

Table 4. Main characteristics of the trip

\begin{tabular}{llll}
\hline & & & \\
\hline Main motivation of the & $\%$ & Accommodation & $\%$ \\
trip & $42.6 \%$ & $4 / 5$-star hotel & $39.4 \%$ \\
Business tourism & $(21.5 \%)$ & 3-star hotel & $47.8 \%$ \\
$\quad$ trade fair & $(21.2 \%)$ & $1 / 2$-star hotel & $3.3 \%$ \\
$\quad$ business meeting & $21.6 \%$ & Residence & $2.0 \%$ \\
Cultural tourism & $(14.8 \%)$ & Friends or relatives & $5.0 \%$ \\
$\quad$ cultural reason & $(2.8 \%)$ & Other & $2.5 \%$ \\
$\quad$ religious reason & $(4 \%)$ & & \\
$\quad$ school trip & $34.5 \%$ & Treatment & $\%$ \\
Leisure tourism & $(16.2 \%)$ & Only bed & $8.7 \%$ \\
$\quad$ leisure & $(4.5 \%)$ & Bed \& breakfast & $60.5 \%$ \\
$\quad$ spa, wellness and sport & Half board & $18.1 \%$ \\
$\quad$ VFR & $(11.5 \%)$ & Full board & $12.7 \%$ \\
shopping & $(2.1 \%)$ & & \\
Other & $1.3 \%$ & Length of stay & $\% .4 \%$ \\
& & One night & $33.2 \%$ \\
Mean of transportation & $\%$ & Two nights & $26.0 \%$ \\
Car & $45.0 \%$ & Three nights & $15.1 \%$ \\
Train & $26.9 \%$ & Four nights & $13.3 \%$ \\
Airplane & $14.9 \%$ & Five to seven nights & $3.1 \%$ \\
$\quad$ airplane only & $(6.5 \%)$ & Eight to fifteen nights & \\
$\quad$ Bus connection & $(8.4 \%)$ & & \\
Boat & $13.0 \%$ & & \\
\hline & $0.3 \%$ & & \\
\hline
\end{tabular}

An important feature that could be linked to our choice experiment is the repetition of the visit to Rimini. As reported in Table 5, only $31.4 \%$ of the sample had never visited Rimini before the interview, and among the $68.6 \%$ of those who previously visited Rimini, $24.2 \%$ of the sample did it for leisure activities during the summer months only, and a high share of respondents (37.6\%) previously stayed in Rimini for both leisure and non-leisure reasons. This result might suggest that there is a high percentage of repeated visits, made by tourists who already knew the city and who might not be interested in increasing the length of the single holiday, at least in this season.

And what about the future? Only $3.2 \%$ of the respondents explicitly excluded future visits to Rimini. It is interesting to notice that, among business tourists who were planning future visits, only $38.9 \%$ of respondents intended (or planned, or needed) to return to Rimini only for business reasons. The remaining $61.1 \%$ suggest that leisure and cultural tourism are potential reasons for returning to Rimini: this 
underlines the key role of business tourism as a tool to promote the cultural and leisure offer of the territory.

Table 5. Previous and Future trips to Rimini.

\begin{tabular}{lllr}
\hline & & & \\
\hline Previous trips to Rimini & $\%$ & Future trips to Rimini & $\%$ \\
Yes & $68.6 \%$ & Yes & $69.5 \%$ \\
No & $31.4 \%$ & No & $3.2 \%$ \\
& & Don't know & $27.3 \%$ \\
Motivation of previous & $\%$ & & \\
trips & & Motivation of future trips & $\%$ \\
Business tourism & $38.2 \%$ & Summer holiday & $31.8 \%$ \\
Leisure tourism & $24.2 \%$ & Leisure holiday & $24.3 \%$ \\
Both types of tourism & $37.6 \%$ & Business trip & $18.1 \%$ \\
& & More than one reason & $26.8 \%$ \\
\hline
\end{tabular}

\subsection{Tourism market segments and latent class analysis}

Generally speaking, it is possible to identify different classes of tourists in two ways: exogenously or endogenously. In the previous section, we described and classified tourists on the basis of observable and characterizing variables, and directly asking what is the main reason for their visit to Rimini. However, such exogenous classification might fail to identify and quantify homogeneous groups of tourists, defined on the basis of intrinsic and unobservable characteristics. For this reason, the questionnaire was built in a way to endogenously identify different segments of tourism through a latent class analysis. ${ }^{22}$ The aim of latent class analysis is to study the influence of socio-economic and demographic variables on the inclusion of individuals in one rather than another segment.

A factor analysis was used to explain individual preferences on tourism consumption. The technique allowed us to extract from data some common factors, in order to reduce the number of explanatory variables which may impact the choice. In this way, it was possible to classify tourists into a few homogeneous groups (or clusters). ${ }^{23}$ The estimation procedure was the principal factors method, although alternative procedures (iteration, maximum likelihood, etc.) did not significantly alter the results. According to several selection criteria (the eigenvalue, the explained variance - see Table A1, Appendix and the screenplot) it was deemed appropriate to extract two common factors. An orthogonal VARIMAX rotation was used. Table A2 (in the Appendix) shows the main characteristics of the variables used in the factor analysis.

The first factor is characterised by people who attach a great value to wellness, leisure and sport activities, love shopping, are associated to sport clubs and self-organize the holiday by making a large use of Internet. This factor is significantly (at the 5\%) correlated with tourists' willingness to visit Rimini again and belong to the group of tourists who recognize in leisure (and not cultural) activities the main reason of their stay in Rimini.

The second factor catches love for cultural activities, a large preference for organized tours, a significant care for the environment, and includes people with higher education, associated to environmental and/or cultural clubs. People largely affected by this factor do not self-organize the holiday and have a shorter

22 Pulido-Fernandez and Sanchez-Rivero (2010) are one of the few examples of latent class analysis used to identify what they call "culturophile tourists".

23 Factor analysis makes possible to obtain a simpler but still informative structure yielded by the correlation between variables. 
stay in Rimini. This factor mainly affects women who recognize in cultural events the main motivation of their stay in Rimini and is significantly correlated with tourists lodging in 4-5 star hotels and with people with higher income.

Factor and cluster analyses allowed us to identify tourism segments on the basis of individual positions in terms of extrapolated factors (Figure A1, Appendix). In this way it was possible to group subjects according to their relative proximity (in terms of Euclidean distance or smaller variability). ${ }^{24}$

Three main clusters have been identified (Figure 1):

1. "Culture lovers" (28.51\% of the sample): tourists who are not much interested in sport and wellness activities but are mainly affected by the cultural assets. On average, they are 50 yearold, predominantly women, have higher incomes and have a short length of stay in Rimini. A large percentage of culture lovers buy organized tours and package holidays.

2. "Leisure lovers" (66.76\% of our sample): tourists who are mainly interested in sport and wellness facilities and are only slightly affected by the cultural offer. On average, they are 38 year-old, have lower incomes and intend to stay in Rimini more than three days. The $75 \%$ of leisure lovers intends to repeat the visit to Rimini and self-organizes the holiday.

3. "Indecisive tourists" ( $4.73 \%$ of our sample): this marginal class includes few individuals who are neither interested in culture nor in leisure activities.

In the next section we compare exogenous segments based on observable variables (thus assuming that subjects with the same characteristics tend to behave similarly) with endogenous and induced segments based on choices and behaviours.

\section{Econometric results}

\subsection{The conditional logit model}

Table 6 presents the results of a conditional logit model estimated for the whole sample and for four subsamples based on whether the trip's main reason is business, cultural, leisure or other. ${ }^{25}$ All the attribute levels, which are described in Table 2, were elaborated as dummy variables, with the exception of the extra-night spent in Rimini (attribute 6 - time value), which took four different quantitative values corresponding to $0,1,1.5$ and 2 (the additional number of days the tourists are willing to spend in Rimini). The 0-values for the dummies were set up on the status quo for each attribute. Since each hypothetical scenario was planned to "improve" the quality of the holiday, we were expecting positive signs for all the coefficients.

\footnotetext{
24 Among the many clustering techniques based on different similarity functions among observations, we used an average linkage method.

${ }_{25} \mathrm{We}$ inserted an alternative-specific constant (ASC) to capture those characteristics of the choice not included otherwise in the model. In our case, there might be a tendency of individuals to prefer any scenario labelled 'A' (on the left of the card presented) over any other scenario labelled ' $\mathrm{B}$ ' (on the right of the card). This is a frequent finding in such models (Louviere et al, 2000), and the inclusion of the alternative-specific constant allows to effectively control for this behaviour. The ASC variable was never significant.
} 

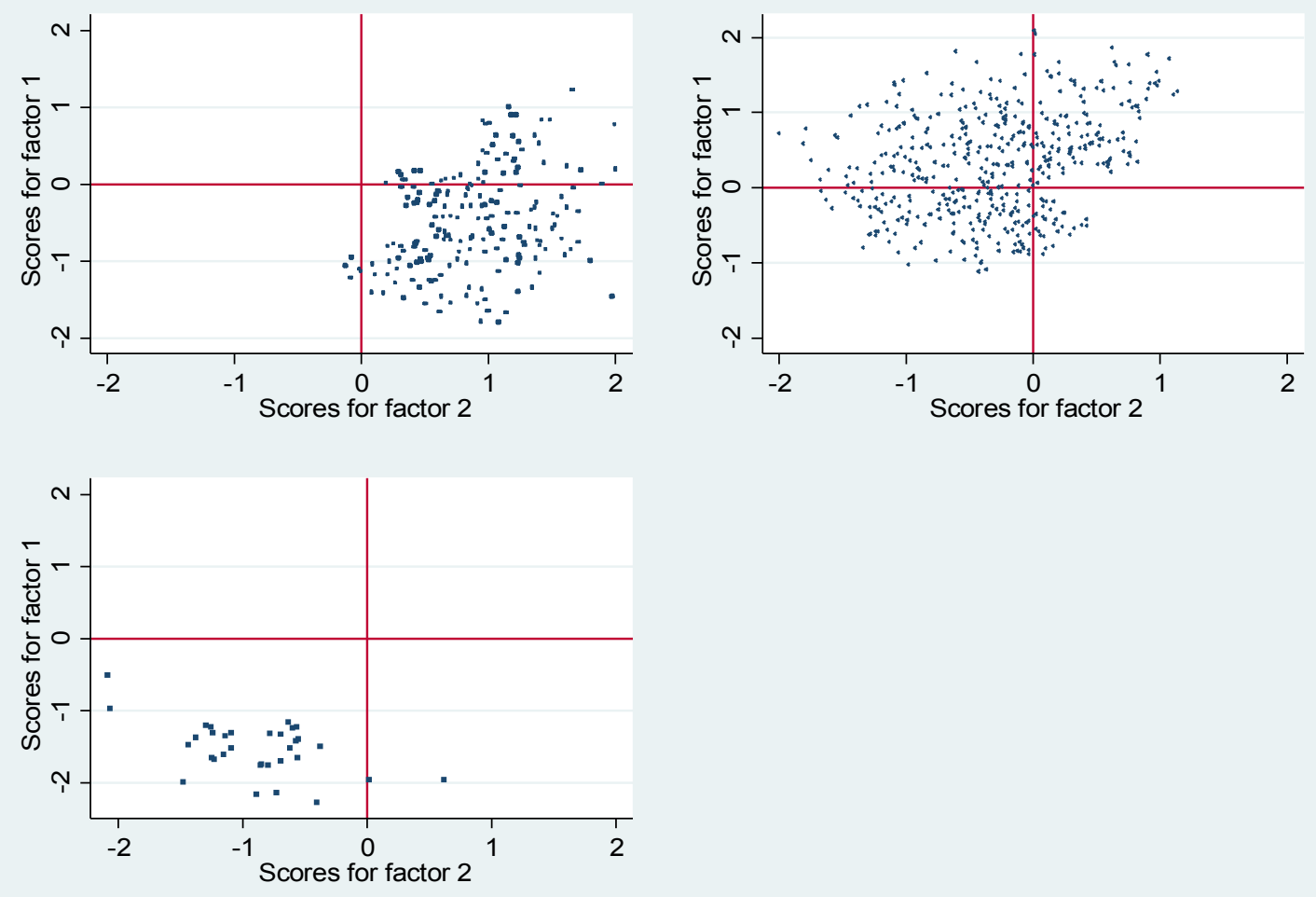

For the whole sample, the maximum likelihood estimates show that all the coefficients were statistically significant and with the expected sign, with the exception of the time attribute (Table 6). As a check on the role played by time, we re-run the model with the time value also inserted as series of dummies (Table 7). Now, the coefficient was significant for the dummies related to one night more and one night more plus one day off-work. The coefficient for the dummy related to two nights more, however, was not significant. All the other coefficients did not change, both in terms of value and significance, in moving from the specification of Table 6 to the one of Table 7. What is the explanation for the different behavior of the time attribute between the two specifications? Probably, the dummies allow to capture the fact that the relationship between choice and time is not linear. While tourists have a positive attitude in spending about one day more in Rimini, in order to take advantage of the whole offer of the city, two days are associated with a very "high price" to pay, given the dimension and the whole offer of the city. The model run in Table 7, however, has a downturn: it is not possible to compute implicit prices to estimate the amount of "time/money" respondents are willing to spend in order to receive a change in the other attributes.

As stated many times before, it is likely that choices depend on many characteristics of the tourists and of the trip. In order to control for preference heterogeneity, we decided to use two main approaches: i) we estimated the main-effect model for different sub-samples identified by the motivation of the trip exogenously stated by tourists; ii) we estimate an extended model including higher order interactions between attribute levels and the motivation of the trip. ${ }^{26}$

26 An alternative way to include preference heterogeneity consists of using the mixed logit model (Train, 2003). However, such approach requires important assumptions on the distributional form of the random parameters. If the distributional form is misspecified the estimates are not consistent. 
Firstly, we estimated the main-effect model for different sub-samples, based on the nature of the trip. Tables 6 and 7 show the results for the models with the time attribute inserted as values (Table 6) and as dummies (Table 7) for business, cultural and leisure tourism. The last column of each table presents results for "other types" of tourism: however, the low number of observations for this case (144) does not allow to suggest any conclusion.

Table 6 Estimation of conditional logit model: whole sample, business tourism, cultural tourism, leisure tourism and other tourism (time attribute inserted in cardinal numbers)

\begin{tabular}{|c|c|c|c|c|c|}
\hline \multirow{2}{*}{$\begin{array}{c}\begin{array}{c}\text { Attributes and } \\
\text { levels }\end{array} \\
\text { Alt. spec. constant }\end{array}$} & \multicolumn{4}{|c|}{ Complete sample Business tourism ${ }^{+}$Cultural tourism $^{++}$Leisure tourism $^{+++}$} & \multirow{3}{*}{$\begin{array}{c}\begin{array}{c}\text { Other types of } \\
\text { tourism }\end{array} \\
0.446 \\
(0.371)\end{array}$} \\
\hline & -0.00319 & 0.00573 & 0.0662 & -0.0431 & \\
\hline & $(0.0270)$ & $(0.0411)$ & $(0.0638)$ & $(0.0463)$ & \\
\hline \multirow[t]{2}{*}{ Organized trip } & $0.0578 * *$ & -0.0132 & $0.487 * * *$ & $-0.102 * *$ & -0.173 \\
\hline & $(0.0270)$ & $(0.0411)$ & $(0.0624)$ & $(0.0463)$ & $(0.311)$ \\
\hline \multirow[t]{2}{*}{ Organized wellness } & $0.285 * * *$ & $0.300 * * *$ & $0.232 * * *$ & $0.262 * * *$ & $1.067 * * *$ \\
\hline & $(0.0270)$ & $(0.0411)$ & $(0.0626)$ & $(0.0465)$ & $(0.364)$ \\
\hline \multirow{2}{*}{$\begin{array}{c}\text { Pedestrian and high } \\
\text { impact }\end{array}$} & $0.136 * * *$ & 0.118 & 0.164 & 0.109 & $1.450^{*}$ \\
\hline & $(0.0464)$ & $(0.0721)$ & $(0.103)$ & $(0.0792)$ & $(0.764)$ \\
\hline \multirow{2}{*}{$\begin{array}{l}\text { Motorized and low } \\
\text { impact }\end{array}$} & $0.181 * * *$ & 0.103 & $0.253^{* *}$ & $0.210^{* *}$ & $1.602 * *$ \\
\hline & $(0.0540)$ & $(0.0822)$ & $(0.126)$ & $(0.0923)$ & $(0.746)$ \\
\hline \multirow{2}{*}{$\begin{array}{c}\text { Pedestrian and low } \\
\text { impact }\end{array}$} & $0.314 * * *$ & $0.171 * *$ & $0.543 * * *$ & $0.351 * * *$ & 0.460 \\
\hline & $(0.0461)$ & $(0.0707)$ & $(0.103)$ & $(0.0809)$ & $(0.511)$ \\
\hline \multirow{2}{*}{ Leisure card } & $0.224 * * *$ & $0.213 * * *$ & 0.189 & $0.258 * * *$ & 0.461 \\
\hline & $(0.0539)$ & $(0.0823)$ & $(0.126)$ & $(0.0923)$ & $(0.633)$ \\
\hline \multirow{2}{*}{ Cultural card } & $0.268 * * *$ & $0.118^{*}$ & $0.720 * * *$ & 0.109 & 0.0157 \\
\hline & $(0.0471)$ & $(0.0716)$ & $(0.105)$ & $(0.0832)$ & $(0.538)$ \\
\hline \multirow{2}{*}{$\begin{array}{l}\text { Leisure \& cultural } \\
\text { card }\end{array}$} & $0.121 * * *$ & $0.141 * *$ & -0.118 & $0.204 * * *$ & 0.0886 \\
\hline & $(0.0466)$ & $(0.0714)$ & $(0.108)$ & $(0.0786)$ & $(0.595)$ \\
\hline \multirow[t]{2}{*}{ Shops open } & $0.149 * * *$ & $0.0993 * *$ & $0.129 * *$ & $0.215 * * *$ & 0.407 \\
\hline & $(0.0270)$ & $(0.0411)$ & $(0.0624)$ & $(0.0464)$ & $(0.352)$ \\
\hline \multirow[t]{2}{*}{ time value } & 0.0292 & 0.0447 & -0.00123 & 0.00932 & 0.359 \\
\hline & $(0.0227)$ & $(0.0347)$ & $(0.0526)$ & $(0.0392)$ & $(0.283)$ \\
\hline Log likelihood & -3860.00 & -1656.69 & -761.98 & -1328.70 & -35.79 \\
\hline Pseudo $\mathrm{R}^{2}$ & 0.02 & 0.02 & 0.11 & 0.03 & 0.28 \\
\hline Nr. of observations & 11468 & 4890 & 2466 & 3968 & 144 \\
\hline
\end{tabular}

Note. Standard errors in parenthesis. *: significant at the $10 \%$ level; **: significant at the $5 \%$ level; ***: significant at the $1 \%$ level.

+ Sample composed by respondents who answered 1, 2, or 3 in question 16.

${ }^{++}$: Sample composed by respondents who answered 5, 7, or 8 in question 16 .

${ }^{+++}$: Sample composed by respondents who answered 4, 6, 9, 10 or 11 in question 16.

Robust results emerged, with important policy implications: firstly, business and leisure tourists, differently from cultural tourists, were not interested in organized trips in the surroundings of Rimini and in discovering their beauty in terms of cultural heritage, food and wine resources and landscape. Secondly, business tourists were very interested in the "leisure card" option, less interested in the "all inclusive" card, and basically not interested in the cultural card package. A similar behavior was detected in leisure tourists. On the other hand, cultural tourists were very interested in the cultural card, less in the "all inclusive" card, not at all interested in the leisure card. These two results suggest synergies between business and leisure tourists, as expected (business travelers stay in the destination if there are available options to relax) and a trade-off between business and cultural tourists, which seem to "fight" for alternative organizations of the holiday. 
However, it is also possible to find synergies. Firstly, all the types of tourists were very interested in "wellness packages"; secondly, they showed to appreciate a different organization of the main attraction of Rimini, the beach and the seaside avenue. Presently, Rimini is heavily built, with more than 1,000 hotels, most of them located on the seaside, and a very organized system of beach services, ${ }^{27}$ with only a tiny amount of the beach which is free-access to tourists. The environmental impact is therefore heavy; moreover, the seaside avenue is open to traffic and there are strong resistances, among local stakeholders, to the pedestrianization of such avenue. However, all tourists showed to appreciate the pedestrianization of the seaside avenue and a different "beach skyline" with less bathing establishments, and with lower environmental impact. The other two levels of the attribute inserted in the experiment (pedestrian avenue with high impact of the beach; avenue open to traffic and low impact of the beach) show mixed results, perhaps because they were seen as contradictory or because interviewed people were not able to clearly differentiate between them.

Table 7 Estimation of conditional logit model: whole sample, business tourism, cultural tourism, leisure tourism and other tourism (time attribute inserted as a series of dummy variables).

\begin{tabular}{|c|c|c|c|c|c|}
\hline \multirow{3}{*}{$\begin{array}{c}\begin{array}{c}\text { Attributes and } \\
\text { levels }\end{array} \\
\text { Alt. spec. constant }\end{array}$} & \multicolumn{5}{|c|}{$\begin{array}{c}\text { Complete sample Business tourism }^{+} \text {Cultural tourism }^{++} \text {Leisure tourism }^{+++} \text {Other }_{\text {tourism }} \\
\text { types }\end{array}$} \\
\hline & -0002 & 0.00753 & 0.0533 & -0.0426 & 0.406 \\
\hline & $(0.0270)$ & $(0.0412)$ & $(0.0648)$ & $(0.0463)$ & $(0.377)$ \\
\hline \multirow[t]{2}{*}{ Organized trip } & $0.057 * *$ & -0.0159 & $0.516^{* * *}$ & $-0.105^{* *}$ & -0.106 \\
\hline & $(0.0270)$ & $(0.0412)$ & $(0.0639)$ & $(0.0465)$ & $(0.326)$ \\
\hline \multirow[t]{2}{*}{ Organized wellness } & $0.286 * * *$ & $0.302 * * *$ & $0.218^{* * *}$ & $0.263 * * *$ & $1.024 * * *$ \\
\hline & $(0.0270)$ & $(0.0412)$ & $(0.0629)$ & $(0.0466)$ & $(0.373)$ \\
\hline \multirow{2}{*}{$\begin{array}{l}\text { Pedestrian and high } \\
\text { impact }\end{array}$} & $0.138 * * *$ & $0.120^{*}$ & 0.160 & 0.110 & $1.394^{*}$ \\
\hline & $(0.0464)$ & $(0.0722)$ & $(0.104)$ & $(0.0793)$ & $(0.770)$ \\
\hline \multirow{2}{*}{$\begin{array}{l}\text { Motorized and low } \\
\text { impact }\end{array}$} & $0.180 * * *$ & 0.0989 & $0.248^{* *}$ & $0.209^{* *}$ & $1.790 * *$ \\
\hline & $(0.0540)$ & $(0.0824)$ & $(0.126)$ & $(0.0925)$ & $(0.776)$ \\
\hline \multirow{2}{*}{$\begin{array}{l}\text { Pedestrian and low } \\
\text { impact }\end{array}$} & $0.315 * * *$ & $0.169 * *$ & $0.521 * * *$ & $0.354 * * *$ & 0.510 \\
\hline & $(0.0461)$ & $(0.0708)$ & $(0.104)$ & $(0.0812)$ & $(0.529)$ \\
\hline \multirow[t]{2}{*}{ Leisure card } & $0.224 * * *$ & $0.216 * * *$ & 0.187 & $0.261 * * *$ & 0.416 \\
\hline & $(0.0539)$ & $(0.0824)$ & $(0.127)$ & $(0.0925)$ & $(0.639)$ \\
\hline \multirow[t]{2}{*}{ Cultural card } & $0.267 * * *$ & $0.120 *$ & $0.714 * * *$ & 0.103 & -0.0314 \\
\hline & $(0.0471)$ & $(0.0717)$ & $(0.105)$ & $(0.0835)$ & $(0.563)$ \\
\hline \multirow{2}{*}{$\begin{array}{l}\text { Leisure \& cultural } \\
\text { card }\end{array}$} & $0.118^{* *}$ & $0.141 * *$ & -0.144 & $0.202 * *$ & 0.120 \\
\hline & $(0.0466)$ & $(0.0715)$ & $(0.111)$ & $(0.0786)$ & $(0.613)$ \\
\hline \multirow[t]{2}{*}{ Shops open } & $0.153 * * *$ & $0.102 * *$ & $0.135^{* *}$ & $0.219 * * *$ & 0.355 \\
\hline & $(0.0270)$ & $(0.0412)$ & $(0.0628)$ & $(0.0465)$ & $(0.361)$ \\
\hline \multirow[t]{2}{*}{ one night more } & $0.1527 * * *$ & $0.178 * *$ & $0.228 * *$ & 0.115 & -0.218 \\
\hline & $\left(\begin{array}{lll}0 & 0541)\end{array}\right.$ & $(0.0711)$ & $(0.115)$ & $(0.0804)$ & $(0.553)$ \\
\hline \multirow{2}{*}{$\begin{array}{l}\text { one night and day } \\
\text { more }\end{array}$} & $0.1233 * * *$ & $0.231 * * *$ & 0.0500 & $0.153^{*}$ & -0.0976 \\
\hline & $\left(\begin{array}{lll}0 & 0472\end{array}\right)$ & $(0.0824)$ & $(0.126)$ & $(0.0924)$ & $(0.674)$ \\
\hline \multirow[t]{2}{*}{ two nights more } & 00399 & 0.0616 & -0.0339 & -0.00244 & 0.878 \\
\hline & $\left(\begin{array}{lll}0 & 0461)\end{array}\right)$ & $(0.0706)$ & $(0.107)$ & $(0.0798)$ & $(0.596)$ \\
\hline Log likelihood & -3855.82 & -1652.61 & -759.18 & -1326.46 & -34.72 \\
\hline Pseudo $\mathrm{R}^{2}$ & 0.03 & 0.02 & 0.11 & 0.04 & 0.30 \\
\hline Nr. of observations & 11468 & 4890 & 2466 & 3968 & 144 \\
\hline
\end{tabular}

Note. Standard errors in parenthesis. *: significant at the $10 \%$ level; **: significant at the 5\% level; ***: significant at the $1 \%$ level.

+: Sample composed by respondents who answered 1,2 , or 3 in question 16 .

${ }^{++}$: Sample composed by respondents who answered 5 , 7, or 8 in question 16

27 During the summer season, there are dozens of bathing establishments, which offer, against a payment, any kind of services to tourists. 
Finally, it is interesting to analyze the coefficients of the time dummies (Table 7). None of the types of tourism were willing to significantly increase the length of stay in Rimini to two days (and paying for it), while, as regards one day more, an important difference emerged in comparing business and cultural tourists: the former were willing to take one day of leave and stay one night more, the latter were only willing to stay one night more. Our interpretation is that cultural tourists take short breaks, mainly in weekends, and therefore they have a strong time constraint, since for most of them it is really difficult to take one day (more) off work: therefore they want "more" in the same amount of time. Business tourists, on the contrary, happen to stay in Rimini for working reasons and most of them, if they can, would be willing to take a day off from work, and pay an extra-night in order to discover the attractions of the city which, during the business meetings, are impossible to visit.

An alternative approach to deal with individual heterogeneity, as stated before, would be to estimate an extended model which includes higher order interactions between attribute levels and the motivation of the trip. In this way it would be possible to check whether preferences for the level of one attribute depend on socio-demographic characteristics. The vast majority of choice experiments use the main effect design only, explicitly or implicitly assuming that interactions among attributes are not significant. However, if interactions are significant, such omission leads to biased results (Hensher et al. 2005). In our experiment, the interaction coefficients were not statistically significant, so we continued the analysis by using the main-effect model only. ${ }^{28}$

\subsection{The in-deep analysis: the model applied to different sub-samples}

In Table 8 we presented the results of the conditional logit model run on different sub-samples. Firstly, we split according to the region of origin of tourists (Italians and Foreigners). The main difference is related to the importance of organized trips (the coefficient was not significant for Foreigners) and to the time attribute (none of the coefficients of the time dummies are significant for Foreigners: clearly, they are not willing to spend more time in Rimini.

In the next columns of Table 8 the breakthrough by age is shown. We highlight the relevance of organized trips (which coefficient was negative and significant for young people), organized wellness (which coefficient was highly significant for all the age groups, except for the elderly), the leisure card (which coefficient was not significant for the elderly), the cultural card (which coefficient was not significant for the young) and the extended opening time of shops (which coefficient, again, was not significant for the elderly). Finally, with respect to the time dummies, the only significant coefficients were for the adults (who were willing to stay one more night) and for the elderly (who were willing to stay two more nights, probably because of their loose time constraint).

Another interesting break-down is between tourists who pay for the trip (basically all the cultural tourists and some of the business tourists) and those tourists who have the trip payed or refunded by their employer (the majority of business tourists). An important difference emerged: the former had a positive attitude with respect to most of the attribute levels that improve the status quo (the only exception being organized trips, which coefficient was not significant). However, the coefficient for the time dummies were just weakly significant (one night, and one night and one day) or not significant (two nights). Probably, all these tourists, who have organized the trip themselves, have already optimized how to spend the time in Rimini among the different activities and attractions. The second group, that might be called the "hard-core" business tourists, were strongly interested in leisure activities (the extended opening of the shops, the leisure card, the organized system of wellness and the organized trip all had significant coefficients), and not interested in what is related with cultural and environmental offer (the coefficients for the pedestrian seaside avenue and for the cultural card were not significant). Moreover, they were willing to stay one night and one day more in Rimini to take advantage of the improved leisure offer.

28 Results are available from the authors upon request. 
Finally, another break-down that we presented is between those tourists who had never been before in Rimini and those who were repeating the visit. The formers were less interested in an improvement of the "Rimini package" and were not willing to pay for spending more time in Rimini, contrary to what happened with repeating tourists (Table 8). The reason is probably to be searched in the fact that the first group includes tourists who rarely go back in the same destination, tourists who happened to be there for other reasons (mainly business) and tourists who just did not like the city and that, therefore, were not interestedin extending the length of stay.

Table 8. Estimation of conditional logit model: different sub-samples

\begin{tabular}{|c|c|c|c|c|c|c|c|c|c|c|}
\hline Attributes and levels & Italians & $\begin{array}{c}\text { Foreigner } \\
\mathbf{s}\end{array}$ & $\begin{array}{l}\text { The } \\
\text { young } \\
(<31)\end{array}$ & $\begin{array}{c}\text { The } \\
\text { adults } \\
(31-45)\end{array}$ & $\begin{array}{c}\text { The } \\
\text { senior } \\
(46-65)\end{array}$ & $\begin{array}{l}\text { The } \\
\text { elderly } \\
(>65)\end{array}$ & $\begin{array}{c}\text { The } \\
\text { tourist } \\
\text { pays }\end{array}$ & $\begin{array}{c}\text { The } \\
\text { company } \\
\text { pays }\end{array}$ & $\begin{array}{l}\text { First time } \\
\text { in Rimini }\end{array}$ & $\begin{array}{c}\text { previous } \\
\text { times in } \\
\text { Rimini }\end{array}$ \\
\hline Alt. spec. constant & $\begin{array}{l}0.00235 \\
(0.0287)\end{array}$ & $\left.\begin{array}{ll}-0 & 0525 \\
(0 & 0833\end{array}\right)$ & $\begin{array}{l}-0.0628 \\
(0.0577)\end{array}$ & $\begin{array}{c}0.0208 \\
(0.0490)\end{array}$ & $\begin{array}{c}0.0262 \\
(0.0437)\end{array}$ & $\begin{array}{l}0.0102 \\
(0.114)\end{array}$ & $\begin{array}{l}-0.0354 \\
(0.0326)\end{array}$ & $\begin{array}{c}0.0646 \\
(0.0489)\end{array}$ & $\begin{array}{l}-0.0119 \\
(0.0485)\end{array}$ & $\begin{array}{l}0.00368 \\
(0.0327)\end{array}$ \\
\hline Organized trip & $\begin{array}{l}0.0591^{* *} \\
(0.0287)\end{array}$ & $\begin{array}{c}00654 \\
(00840)\end{array}$ & $\begin{array}{c}-0.220 * * * \\
(0.0571)\end{array}$ & $\begin{array}{l}0.119 * * \\
(0.0489)\end{array}$ & $\begin{array}{l}0.109 * * \\
(0.0438)\end{array}$ & $\begin{array}{c}0.460^{* * *} \\
(0.112)\end{array}$ & $\begin{array}{c}0.0275 \\
(0.0326)\end{array}$ & $\begin{array}{c}0.126^{* * *} \\
(0.0488)\end{array}$ & $\begin{array}{c}0.0561 \\
(0.0485)\end{array}$ & $\begin{array}{l}0.0622^{*} \\
(0.0327)\end{array}$ \\
\hline Organized wellness & $\begin{array}{c}0.281^{* * *} \\
(0.0287)\end{array}$ & $\begin{array}{c}03432 * * * \\
(00851)\end{array}$ & $\begin{array}{c}0.453^{* * * *} \\
(0.0576)\end{array}$ & $\begin{array}{c}0.283 * * * \\
(0.0490)\end{array}$ & $\begin{array}{l}0.226^{* * *} \\
(0.0438)\end{array}$ & $\begin{array}{c}0.00858 \\
(0.112)\end{array}$ & $\begin{array}{c}0.308^{* * * *} \\
(0.0327)\end{array}$ & $\begin{array}{l}0.242 * * * \\
(0.0488)\end{array}$ & $\begin{array}{c}0.282^{* * *} \\
(0.0486)\end{array}$ & $\begin{array}{c}0.291 * * * \\
(0.0327)\end{array}$ \\
\hline Ped. and high impact & $\begin{array}{c}0.131^{* * *} \\
(0.0496)\end{array}$ & $\begin{array}{l}0 \text { 2293* } \\
(01392)\end{array}$ & $\begin{array}{c}0.0568 \\
(0.0956)\end{array}$ & $\begin{array}{l}0.218^{* *} \\
(0.0848)\end{array}$ & $\begin{array}{c}0.138^{*} \\
(0.0754)\end{array}$ & $\begin{array}{c}0.190 \\
(0.206)\end{array}$ & $\begin{array}{l}0.137^{* *} \\
(0.0559)\end{array}$ & $\begin{array}{c}0.155^{*} \\
(0.0845)\end{array}$ & $\begin{array}{c}0.0776 \\
(0.0825)\end{array}$ & $\begin{array}{c}0.168^{* * *} \\
(0.0565)\end{array}$ \\
\hline Motor and low impact & $\begin{array}{c}0.151^{* * *} \\
(0.0574)\end{array}$ & $\begin{array}{c}04382 * * * \\
(01655)\end{array}$ & $\begin{array}{c}0.280^{* *} \\
(0.115)\end{array}$ & $\begin{array}{c}0.258 * * * \\
(0.0978)\end{array}$ & $\begin{array}{c}0.133 \\
(0.0873)\end{array}$ & $\begin{array}{c}0.260 \\
(0.227)\end{array}$ & $\begin{array}{c}0.258^{* * * *} \\
(0.0652)\end{array}$ & $\begin{array}{c}0.0205 \\
(0.0976)\end{array}$ & $\begin{array}{c}0.133 \\
(0.0968)\end{array}$ & $\begin{array}{c}0.200^{* * *} \\
(0.0653)\end{array}$ \\
\hline Pedes. and low impact & $\begin{array}{c}0.291 * * * \\
(0.0488)\end{array}$ & $\begin{array}{c}05423^{* * *} \\
(01479)\end{array}$ & $\begin{array}{c}0.298 * * * \\
(0.0939)\end{array}$ & $\begin{array}{c}0.290 * * * \\
(0.0853)\end{array}$ & $\begin{array}{c}0.306 * * * \\
(0.0737)\end{array}$ & $\begin{array}{c}0.652 * * * \\
(0.211)\end{array}$ & $\begin{array}{c}0.416^{* * * *} \\
(0.0564)\end{array}$ & $\begin{array}{c}0.118 \\
(0.0813)\end{array}$ & $\begin{array}{c}0.287 * * * \\
(0.0827)\end{array}$ & $\begin{array}{c}0.329 * * * \\
(0.0557)\end{array}$ \\
\hline Leisur & $\begin{array}{c}0.209 * * * \\
(0.0573)\end{array}$ & $\begin{array}{l}0.209 * * \\
\left(\begin{array}{ll}0 & 1639\end{array}\right)\end{array}$ & $\begin{array}{c}0.293 * * * \\
(0.113)\end{array}$ & $\begin{array}{c}0.141 \\
(0.0980)\end{array}$ & $\begin{array}{l}0.225^{* *} \\
(0.0872)\end{array}$ & $\begin{array}{c}0.172 \\
(0.222)\end{array}$ & $\begin{array}{c}0.246^{* * *} \\
(0.0651)\end{array}$ & $\begin{array}{l}0.197 * * \\
(0.0974)\end{array}$ & $\begin{array}{c}0.165^{*} \\
(0.0966)\end{array}$ & $\begin{array}{c}0.254 * * * \\
(0.0652)\end{array}$ \\
\hline Cultural card & $\begin{array}{l}0.243^{* * *} \\
(0.0496)\end{array}$ & $\begin{array}{l}0557 * * * \\
(01569)\end{array}$ & $\begin{array}{c}0.0677 \\
(0.0985)\end{array}$ & $\begin{array}{l}0.240^{* * *} \\
(0.0842)\end{array}$ & $\begin{array}{l}0.321 * * * \\
(0.0761)\end{array}$ & $\begin{array}{c}0.730 * * * \\
(0.190)\end{array}$ & $\begin{array}{l}0.344 * * * \\
(0.0574)\end{array}$ & $\begin{array}{c}0.114 \\
(0.0834)\end{array}$ & $\begin{array}{l}0.286^{* * *} \\
(0.0849)\end{array}$ & $\begin{array}{l}0.267 * * * \\
(0.0568)\end{array}$ \\
\hline Leisure/cultural card & $\begin{array}{l}0.114 * * \\
(0.0497)\end{array}$ & $\begin{array}{c}01668 \\
(01388)\end{array}$ & $\begin{array}{c}0.0950 \\
(0.0981)\end{array}$ & $\begin{array}{c}0.0448 \\
(0.0844)\end{array}$ & $\begin{array}{l}0.188 * * \\
(0.0758)\end{array}$ & $\begin{array}{l}0.199 \\
(0.199)\end{array}$ & $\begin{array}{l}0.141 * * \\
(0.0559)\end{array}$ & $\begin{array}{c}0.0755 \\
(0.0850)\end{array}$ & $\begin{array}{c}0.0361 \\
(0.0831)\end{array}$ & $\begin{array}{l}0.157 * * * \\
(0.0565)\end{array}$ \\
\hline Shops open & $\begin{array}{l}0.145^{* * * *} \\
(0.0287)\end{array}$ & $\begin{array}{l}01986^{* *} \\
(00846)\end{array}$ & $\begin{array}{l}0.252 * * * \\
(0.0573)\end{array}$ & $\begin{array}{l}0.120 * * \\
(0.0489)\end{array}$ & $\begin{array}{l}0.125 * * * \\
(0.0437)\end{array}$ & $\begin{array}{l}0.0156 \\
(0.111)\end{array}$ & $\begin{array}{l}0.153 * * * \\
(0.0327)\end{array}$ & $\begin{array}{c}0.146^{* * *} \\
(0.0488)\end{array}$ & $\begin{array}{l}0.165 * * * \\
(0.0485)\end{array}$ & $\begin{array}{l}0.147 * * * \\
(0.0327)\end{array}$ \\
\hline one night more & $\begin{array}{l}0.159^{* * *} \\
(0.0501)\end{array}$ & $\begin{array}{l}-0194 \\
\left(\begin{array}{ll}0 & 1440)\end{array}\right)\end{array}$ & $\begin{array}{l}-0.0487 \\
(0.103)\end{array}$ & $\begin{array}{l}0.274 * * * \\
(0.0852)\end{array}$ & $\begin{array}{c}0.113 \\
(0.0762)\end{array}$ & $\begin{array}{l}0.0825 \\
(0.181)\end{array}$ & $\begin{array}{c}0.109 * \\
(0.0568)\end{array}$ & $\begin{array}{c}0.156^{*} \\
(0.0854)\end{array}$ & $\begin{array}{l}-0.0200 \\
(0.0849)\end{array}$ & $\begin{array}{l}0.186^{* * *} \\
(0.0569)\end{array}$ \\
\hline $\begin{array}{l}\text { one night and one } \\
\text { day more }\end{array}$ & $0.180^{* * *}$ & -00940 & 0.139 & $0.211^{* *}$ & 0.137 & 0.0147 & $0.122 *$ & $0.213 * *$ & 0.105 & $0.173 * * *$ \\
\hline & $(0.0574)$ & (0 1644) & $(0.114)$ & $(0.0978)$ & $(0.0876)$ & $(0.223)$ & $(0.0652)$ & $(0.0977)$ & $(0.0967)$ & $(0.0654)$ \\
\hline two nights more & $\begin{array}{c}0.0499 \\
(0.0489)\end{array}$ & $\begin{array}{l}-00657 \\
\left(\begin{array}{ll}0 & 1423)\end{array}\right)\end{array}$ & $\begin{array}{c}0.150 \\
(0.0940)\end{array}$ & $\begin{array}{c}0.0202 \\
(0.0863)\end{array}$ & $\begin{array}{c}0.0618 \\
(0.0735)\end{array}$ & $\begin{array}{l}-0.387^{*} \\
(0.199)\end{array}$ & $\begin{array}{c}0.0207 \\
(0.0561)\end{array}$ & $\begin{array}{c}0.0716 \\
(0.0821)\end{array}$ & $\begin{array}{c}0.0695 \\
(0.0830)\end{array}$ & $\begin{array}{c}0.0271 \\
(0.0557)\end{array}$ \\
\hline Log likelihood & -3416.77 & -432.62 & -898.37 & -1179.16 & -1478.81 & -241.67 & -2658.02 & -1184.55 & -1204.47 & -2640.45 \\
\hline Pseudo $\mathrm{R}^{2}$ & 0.03 & 0.05 & 0.07 & 0.03 & 0.03 & 0.11 & 0.04 & 0.02 & 0.03 & 0.03 \\
\hline Nr. of observations & 10148 & 1320 & 2784 & 3520 & 4384 & 780 & 7970 & 3498 & 3580 & 7872 \\
\hline
\end{tabular}

Note. *: significant at the $10 \%$ level; **: significant at the $5 \%$ level; ***: significant at the $1 \%$ level.

In Table 9, other break-downs of the whole sample were proposed. Firstly, we aggregated the different occupational categories into three groups: managers (including entrepreneurs, managers and professionals), white collars (including traders, employees and teachers), others (blue collars, students, unemployed and retired persons). Some interesting differences emerged: firstly, there is a different pattern 
of organization of the free time: managers dislike organized trips (although not significant, the coefficient has a negative sign), which are, on the contrary, much appreciated by the middle class; they liked the system of wellness and the "pedestrian" seaside, although less than the middle class and the residual class. The other coefficients did not raise any surprise, except the fact that the all-inclusive card option was not particularly appreciated. Interestingly, the managers were willing to stay one night more only, while white collars were also willing to spend an extra-day, probably due to the fact that the former have less opportunities to stay another day away from work (or their opportunity cost is too high).

Table 9. Estimation of conditional logit model: different sub-samples

\begin{tabular}{|c|c|c|c|c|c|c|c|c|c|}
\hline \multicolumn{2}{|c|}{ Attributes and levels Managers } & \multirow{2}{*}{$\begin{array}{c}\text { White } \\
\text { collars }\end{array}$} & \multirow{2}{*}{$\begin{array}{c}\text { Others } \\
-0.0440 \\
(0.0527)\end{array}$} & \multirow{2}{*}{$\begin{array}{c}\begin{array}{c}\text { Low } \\
\text { income }\end{array} \\
-0.0316 \\
(0.0424)\end{array}$} & \multirow{2}{*}{$\begin{array}{c}\text { Middle } \\
\text { income }\end{array}$} & \multirow{2}{*}{$\begin{array}{c}\begin{array}{c}\text { High } \\
\text { income }\end{array} \\
-0.0213 \\
(0.0462)\end{array}$} & \multirow{2}{*}{$\begin{array}{c}\text { 4/5 stars } \\
-0.0137 \\
(0.0440)\end{array}$} & \multirow{2}{*}{$\begin{array}{c}3 \text { stars } \\
0.0255 \\
(0.0389)\end{array}$} & \multirow{2}{*}{$\begin{array}{c}\text { Others } \\
-0.0535 \\
(0.0830)\end{array}$} \\
\hline Alt. spec. constant & $\begin{array}{c}0.0261 \\
(0.0539)\end{array}$ & & & & & & & & \\
\hline Organized trip & $\begin{array}{l}-0.0134 \\
(0.0538)\end{array}$ & $\begin{array}{l}0.101^{* *} \\
(0.0405)\end{array}$ & $\begin{array}{c}0.0785 \\
(0.0529)\end{array}$ & $\begin{array}{l}-0.0647 \\
(0.0424)\end{array}$ & $\begin{array}{c}0.0963^{*} \\
(0.0563)\end{array}$ & $\begin{array}{c}0.162 * * * \\
(0.0461)\end{array}$ & $\begin{array}{c}0.0939 * * \\
(0.0437)\end{array}$ & $\begin{array}{c}0.0389 \\
(0.0389)\end{array}$ & $\begin{array}{c}-0.0340 \\
(0.0930)\end{array}$ \\
\hline Organized wellness & $\begin{array}{c}0.393 * * * \\
(0.0538)\end{array}$ & $\begin{array}{c}0.270^{* * *} \\
(0.0405)\end{array}$ & $\begin{array}{c}0.208 * * * \\
(0.0531)\end{array}$ & $\begin{array}{c}0.247 * * * \\
(0.0424)\end{array}$ & $\begin{array}{c}0.186^{* * * *} \\
(0.0563)\end{array}$ & $\begin{array}{c}0.406 * * * \\
(0.0461)\end{array}$ & $\begin{array}{c}0.323 * * * \\
(0.0435)\end{array}$ & $\begin{array}{c}0.240^{* * * *} \\
(0.0389)\end{array}$ & $\begin{array}{c}0.320^{* * *} \\
(0.0960)\end{array}$ \\
\hline Ped. and high impact & $\begin{array}{c}0.0804 \\
(0.0930)\end{array}$ & $\begin{array}{c}0.189 * * * \\
(0.0704)\end{array}$ & $\begin{array}{c}0.111 \\
(0.0895)\end{array}$ & $\begin{array}{c}0.195 * * * \\
(0.0740)\end{array}$ & $\begin{array}{c}0.187^{*} \\
(0.0965)\end{array}$ & $\begin{array}{c}0.0549 \\
(0.0779)\end{array}$ & $\begin{array}{l}0.185^{* *} \\
(0.0746)\end{array}$ & $\begin{array}{c}0.0735 \\
(0.0679)\end{array}$ & $\begin{array}{c}0.167 \\
(0.141)\end{array}$ \\
\hline Motor and low impact & $\begin{array}{c}0.115 \\
(0.108)\end{array}$ & $\begin{array}{l}0.177^{* *} \\
(0.0809)\end{array}$ & $\begin{array}{c}0.164 \\
(0.105)\end{array}$ & $\begin{array}{l}0.203^{* *} \\
(0.0848)\end{array}$ & $\begin{array}{c}0.141 \\
(0.111)\end{array}$ & $\begin{array}{l}0.200 * * \\
(0.0921)\end{array}$ & $\begin{array}{c}0.139 \\
(0.0873)\end{array}$ & $\begin{array}{l}0.184 * * \\
(0.0779)\end{array}$ & $\begin{array}{c}0.348^{* *} \\
(0.157)\end{array}$ \\
\hline Pedes. and low impact & $\begin{array}{c}0.282 * * * \\
(0.0898)\end{array}$ & $\begin{array}{c}0.236^{* * *} \\
(0.0689)\end{array}$ & $\begin{array}{c}0.406 * * * \\
(0.0921)\end{array}$ & $\begin{array}{c}0.363 * * * \\
(0.0723)\end{array}$ & $\begin{array}{l}0.242 * * \\
(0.0976)\end{array}$ & $\begin{array}{c}0.319^{* * *} \\
(0.0775)\end{array}$ & $\begin{array}{c}0.271 * * * \\
(0.0719)\end{array}$ & $\begin{array}{c}0.306^{* * *} * \\
(0.0683)\end{array}$ & $\begin{array}{c}0.466^{* * * *} \\
(0.151)\end{array}$ \\
\hline Leisure card & $\begin{array}{l}0.206^{*} \\
(0.107)\end{array}$ & $\begin{array}{c}0.251 * * * \\
(0.0809)\end{array}$ & $\begin{array}{c}0.252^{* *} \\
(0.105)\end{array}$ & $\begin{array}{c}0.260 * * * \\
(0.0848)\end{array}$ & $\begin{array}{l}0.215^{*} \\
(0.112)\end{array}$ & $\begin{array}{c}0.183^{* *} \\
(0.0918)\end{array}$ & $\begin{array}{c}0.254 * * * \\
(0.0872)\end{array}$ & $\begin{array}{c}0.190^{* *} \\
(0.0778)\end{array}$ & $\begin{array}{c}0.249 \\
(0.164)\end{array}$ \\
\hline Cultural card & $0.231 * *$ & $0.306^{* * *}$ & $0.269 * * *$ & $0.236 * * *$ & 0.0909 & $0.406^{* * *}$ & $0.294 * * *$ & $0.297 * * *$ & -0.0580 \\
\hline & $(0.0917)$ & $(0.0703)$ & $(0.0944)$ & $(0.0728)$ & $(0.101)$ & $(0.0799)$ & $(0.0732)$ & $(0.0680)$ & $(0.170)$ \\
\hline Leisure/cultural card & 0.0883 & $0.170 * *$ & 0.0734 & $0.194 * * *$ & 0.102 & 0.0272 & 0.114 & 0.0775 & $0.242 *$ \\
\hline & $(0.0936)$ & $(0.0701)$ & $(0.0895)$ & $(0.0737)$ & $(0.0957)$ & $(0.0790)$ & $(0.0761)$ & $(0.0671)$ & $(0.146)$ \\
\hline Shops open & $0.122 * *$ & $0.113 * * *$ & $0.259 * * *$ & $0.191 * * *$ & 0.0767 & $0.155^{* * *}$ & $0.208 * * *$ & $0.102 * * *$ & 0.120 \\
\hline & $(0.0538)$ & $(0.0405)$ & $(0.0530)$ & $(0.0424)$ & $(0.0558)$ & $(0.0461)$ & $(0.0435)$ & $(0.0389)$ & $(0.0855)$ \\
\hline one night more & $0.229 * *$ & 0.103 & 0.0931 & $0.131^{*}$ & 0.0924 & $0.143^{*}$ & $0.131^{*}$ & $0.174 * * *$ & -0.00308 \\
\hline & $(0.0949)$ & $(0.0702)$ & $(0.0919)$ & $(0.0739)$ & $(0.0955)$ & $(0.0817)$ & $(0.0778)$ & $(0.0668)$ & $(0.146)$ \\
\hline one night and one & 0.164 & $0.182 * *$ & 0.134 & $0.207 * *$ & 0.00649 & $0.195^{* *}$ & $0.160^{*}$ & $0.167 * *$ & 0.0633 \\
\hline & $(0.108)$ & $(0.0810)$ & $(0.105)$ & $(0.0848)$ & $(0.112)$ & $(0.0920)$ & $(0.0872)$ & $(0.0778)$ & $(0.163)$ \\
\hline two nights more & 0.0608 & 0.0889 & -0.0673 & 0.0629 & -0.000121 & 0.0416 & 0.0232 & 0.0603 & -0.0454 \\
\hline & $(0.0909)$ & $(0.0691)$ & $(0.0912)$ & $(0.0726)$ & $(0.0950)$ & $(0.0786)$ & $(0.0735)$ & $(0.0681)$ & $(0.136)$ \\
\hline Log likelihood & -980.63 & -1714.99 & -1025.59 & -1565.68 & -912.25 & -1351.72 & -1504.29 & -1850.62 & -488.71 \\
\hline Pseudo $\mathrm{R}^{2}$ & 0.04 & 0.03 & 0.04 & 0.03 & 0.02 & 0.05 & 0.04 & 0.02 & 0.04 \\
\hline Nr. of observations & 2,948 & 5,088 & 3,072 & 4,672 & 2,674 & 4,122 & 4,522 & 5,474 & 1,472 \\
\hline
\end{tabular}

Note. *: significant at the $10 \%$ level; **: significant at the 5\% level; ***: significant at the $1 \%$ level.

However, it would be wrong to link these preferences to income. In fact, in the next three columns of Table 9, a break-down with respect to income is presented, and we can see that choices of high-income recipients do not overlap with those of managers. Time constraints and the responsibilities linked with the professions seem a more important factor than income in affecting the willingness to extend their stay and the other attributes. 
A break-down with respect to the type of accommodation was also presented in the last three columns of Table 9. It seems that there was a mild overlapping between this aggregation and the one based on professions.

Table 10. Estimation of conditional logit model: different sub-samples

\begin{tabular}{|c|c|c|c|c|c|c|c|}
\hline Attributes and levels & 1/2 days & 3 days & 4/6 days & $7 / 15$ days & $\begin{array}{c}\text { Cultural } \\
\text { lovers }\end{array}$ & $\begin{array}{c}\text { Leisure } \\
\text { lovers }\end{array}$ & $\begin{array}{c}\text { Indecisive } \\
\text { tourists }\end{array}$ \\
\hline Alt. spec. constant & $\begin{array}{c}0.0468 \\
(0.0417)\end{array}$ & $\begin{array}{l}-0.0481 \\
(0.0532)\end{array}$ & $\begin{array}{c}0.0605 \\
(0.0598)\end{array}$ & $\begin{array}{c}-0.196^{* *} \\
(0.0860)\end{array}$ & $\begin{array}{c}0.0579 \\
(0.0537)\end{array}$ & $\begin{array}{l}-0.0136 \\
(0.0342)\end{array}$ & $\begin{array}{l}0.0223 \\
(0.130)\end{array}$ \\
\hline Organized trip & $\begin{array}{c}0.0107 \\
(0.0417)\end{array}$ & $\begin{array}{l}0.125 * * \\
(0.0532)\end{array}$ & $\begin{array}{c}0.0921 \\
(0.0596)\end{array}$ & $\begin{array}{l}-0.0269 \\
(0.0855)\end{array}$ & $\begin{array}{c}0.422 * * * \\
(0.0540)\end{array}$ & $\begin{array}{c}-0.101 * * * \\
(0.0342)\end{array}$ & $\begin{array}{c}0.00343 \\
(0.131)\end{array}$ \\
\hline Organized wellness & $\begin{array}{c}0.297 * * * \\
(0.0417)\end{array}$ & $\begin{array}{c}0.274 * * * \\
(0.0533)\end{array}$ & $\begin{array}{c}0.270 * * * \\
(0.0597)\end{array}$ & $\begin{array}{c}0.302 * * * \\
(0.0864)\end{array}$ & $\begin{array}{l}0.0924 * \\
(0.0539)\end{array}$ & $\begin{array}{c}0.439 * * * \\
(0.0342)\end{array}$ & $\begin{array}{c}-0.304 * * \\
(0.132)\end{array}$ \\
\hline Ped. and high impact & $\begin{array}{l}0.150 * * \\
(0.0720)\end{array}$ & $\begin{array}{l}0.223 * * \\
(0.0941)\end{array}$ & $\begin{array}{r}-0.0137 \\
(0.101)\end{array}$ & $\begin{array}{l}0.272^{*} \\
(0.142)\end{array}$ & $\begin{array}{l}0.182 * * \\
(0.0926)\end{array}$ & $\begin{array}{c}0.181 * * * \\
(0.0584)\end{array}$ & $\begin{array}{l}-0.254 \\
(0.228)\end{array}$ \\
\hline Motor and low impact & $\begin{array}{l}0.176^{* *} \\
(0.0833)\end{array}$ & $\begin{array}{l}0.208^{*} \\
(0.106)\end{array}$ & $\begin{array}{l}0.0338 \\
(0.119)\end{array}$ & $\begin{array}{c}0.488 * * * \\
(0.171)\end{array}$ & $\begin{array}{c}0.307 * * * \\
(0.107)\end{array}$ & $\begin{array}{l}0.151 * * \\
(0.0682)\end{array}$ & $\begin{array}{c}0.195 \\
(0.258)\end{array}$ \\
\hline Pedes. and low impact & $\begin{array}{c}0.384 * * * \\
(0.0718)\end{array}$ & $\begin{array}{c}0.252^{* * *} \\
(0.0896)\end{array}$ & $\begin{array}{c}0.266^{* * * *} \\
(0.1000)\end{array}$ & $\begin{array}{c}0.338^{* *} \\
(0.148)\end{array}$ & $\begin{array}{c}0.574 * * * \\
(0.0920)\end{array}$ & $\begin{array}{c}0.275^{* * *} \\
(0.0581)\end{array}$ & $\begin{array}{l}0.418^{*} \\
(0.224)\end{array}$ \\
\hline Leisure card & $\begin{array}{l}0.168^{* *} \\
(0.0832)\end{array}$ & $\begin{array}{c}0.259^{* *} \\
(0.106)\end{array}$ & $\begin{array}{c}0.234 * * \\
(0.119)\end{array}$ & $\begin{array}{c}0.371^{* *} \\
(0.170)\end{array}$ & $\begin{array}{l}0.199^{*} \\
(0.107)\end{array}$ & $\begin{array}{c}0.249 * * * \\
(0.0680)\end{array}$ & $\begin{array}{l}-0.233 \\
(0.258)\end{array}$ \\
\hline \multirow[t]{2}{*}{ Cultural card } & $0.247 * * *$ & $0.207 * *$ & $0.425^{* * *}$ & 0.243 & $0.793^{* * *}$ & 0.0596 & -0.0240 \\
\hline & $(0.0727)$ & $(0.0908)$ & $(0.104)$ & $(0.153)$ & $(0.0938)$ & $(0.0594)$ & $(0.215)$ \\
\hline \multirow[t]{2}{*}{ Leisure/cultural card } & 0.0115 & 0.0882 & $0.264^{* *}$ & $0.377^{* * *}$ & $0.217^{* *}$ & $0.126^{* *}$ & -0.0412 \\
\hline & $(0.0717)$ & $(0.0931)$ & $(0.103)$ & $(0.144)$ & $(0.0933)$ & $(0.0585)$ & $(0.230)$ \\
\hline \multirow[t]{2}{*}{ Shops open } & $0.134 * * *$ & $0.135 * *$ & $0.132 * *$ & $0.280 * * *$ & 0.0323 & $0.196^{* * *}$ & 0.107 \\
\hline & $(0.0417)$ & $(0.0532)$ & $(0.0597)$ & $(0.0860)$ & $(0.0538)$ & $(0.0342)$ & $(0.130)$ \\
\hline \multirow[t]{2}{*}{ one night more } & $0.214 * * *$ & $0.156^{*}$ & 0.0192 & -0.177 & -0.0130 & $0.178^{* * *}$ & 0.299 \\
\hline & $(0.0723)$ & $(0.0919)$ & $(0.105)$ & $(0.153)$ & $(0.0922)$ & $(0.0604)$ & $(0.225)$ \\
\hline \multirow{2}{*}{$\begin{array}{l}\text { one night and one } \\
\text { day more }\end{array}$} & $0.216^{* * *}$ & $0.212 * *$ & 0.0241 & -0.0369 & -0.0468 & $0.235^{* * *}$ & $0.602 * *$ \\
\hline & $(0.0833)$ & $(0.106)$ & $(0.119)$ & $(0.169)$ & $(0.108)$ & $(0.0681)$ & $(0.260)$ \\
\hline \multirow[t]{2}{*}{ two nights more } & 0.0191 & 0.0595 & 0.121 & -0.103 & -0.132 & $0.166^{* * *}$ & 0.0571 \\
\hline & $(0.0718)$ & $(0.0897)$ & $(0.100)$ & $(0.149)$ & $(0.0912)$ & $(0.0587)$ & $(0.223)$ \\
\hline Log likelihood & -1622.94 & -1000.43 & -801.64 & -405.38 & -1002.03 & -2449.66 & -172.39 \\
\hline Pseudo $\mathrm{R}^{2}$ & 0.03 & 0.03 & 0.04 & 0.06 & 0.09 & 0.05 & 0.06 \\
\hline Nr. of observations & 4,850 & 2,976 & 2,400 & 1,242 & 3,176 & 7,450 & 528 \\
\hline
\end{tabular}

Note. *: significant at the $10 \%$ level; **: significant at the $5 \%$ level; $* * *$ : significant at the $1 \%$ level.

In Table 10 some other checks were carried out. In the first four columns, the break-down by length of stay was presented. Not surprisingly, the most important difference is about the willingness to stay one night more and one night and one day more: positive and significant for tourists who stay one or two days, not significant for all the others. ${ }^{29}$

Finally, in the last three columns, the same conditional logit model has been estimated for each endogenous cluster obtained in the latent class analysis carried out in Section 3.1. Cultural lovers mainly prefer organized tours, which include also the availability of cultural and all-inclusive cards to access different types of tourism facilities, but are not willing to spend extra-time in Rimini. On the contrary,

29 For a city like Rimini, three days are considered enough for a visit off-season. 
leisure lovers are willing to spend more time in the same location, to do shopping even during the night and on Sundays and to access wellness facilities. They would appreciate the availability of leisure or allinclusive cards. Both cultural and leisure lovers' choices are positively affected by environmental-friendly investments which reduce beach impacts and provide for the pedestrianization of the seaside avenue. Overall, the endogenous clustering seems able to split more precisely between the different needs and demands of tourists in Rimini.

\section{Choice probability of different scenarios and policy discussion}

Choice experiments can help policy makers since it is possible to create alternative hypothetical scenarios by mixing attribute levels. We built four scenarios differing in the level of five attributes of the choice experiments (the time variable was excluded): the status quo, the "cultural scenario", the "leisure" scenario, the "environmental friendly" scenario, which characteristics and levels are presented in Table 11. It has to be recalled that this simulation, which considers more than two alternatives at the same time, is based on the IIA assumption.

Table 11. Simulation of the distribution of choice probabilities in the case of four scenarios

\begin{tabular}{|c|c|c|c|c|}
\hline Attribute & status quo & $\begin{array}{c}\text { cultural } \\
\text { scenario }\end{array}$ & $\begin{array}{c}\text { leisure } \\
\text { scenario }\end{array}$ & $\begin{array}{c}\text { environmental } \\
\text { scenario }\end{array}$ \\
\hline day trip & not organized & organized & not organized & organized \\
\hline wellness, sport & not organized & not organized & organized & organized \\
\hline environment impact & $\begin{array}{c}\text { high beach } \\
\text { impact and } \\
\text { motor. avenue }\end{array}$ & $\begin{array}{c}\text { high beach } \\
\text { impact and } \\
\text { ped. avenue }\end{array}$ & $\begin{array}{c}\text { high beach } \\
\text { impact and } \\
\text { ped. avenue }\end{array}$ & $\begin{array}{c}\text { low beach } \\
\text { impact and ped. } \\
\text { avenue }\end{array}$ \\
\hline holiday cards & no card & cultural card & leisure card & $\begin{array}{c}\text { cultural and } \\
\text { leisure cards }\end{array}$ \\
\hline shops open & close & close & open & close \\
\hline Choice probabilities & $14.34 \%$ & $22.75 \%$ & $31.71 \%$ & $31.20 \%$ \\
\hline Complete sample & $16.27 \%$ & $20.33 \%$ & $33.78 \%$ & $29.62 \%$ \\
\hline Business tourism & $9.88 \%$ & $38.92 \%$ & $20.18 \%$ & $31.02 \%$ \\
\hline Cultural tourism & $17.11 \%$ & $27.56 \%$ & $34.97 \%$ & $20.36 \%$ \\
\hline Leisure tourism & & & & \\
\hline
\end{tabular}

We inferred from the econometric estimates the probability that tourists choose one of these scenarios, ${ }^{30}$ thus leading to interesting implications for the policy agenda. The inspection of Table 11 suggests that the leisure scenario was the most favorite by business and leisure tourists while, for the whole sample, the environmental scenario was as likely to be chosen. Not surprisingly, the cultural scenario was the first best for cultural tourists. However, there is one important difference among business and leisure tourists, which lies in their second best: for business tourists it was the environmental scenario, while for leisure

30 The probability that an individual picked each scenario out of the four alternatives was computed by inserting in equation (2.2) the coefficient estimated in Tables 7. 
tourists it was the cultural scenario. The least preferred scenario is, by all groups, the status quo: indeed, there is room for improvements in the organization of Rimini's tourism policy. It appears that the environmental scenario is more balanced, and can be positively accepted by all types of tourism which Rimini hosts off-season. However, it is probably very costly to implement. Alternatively, if a budget constraint is active in the destination, it appears that the policy makers have to choose between two opposite models of off-season tourism development: the cultural and the leisure model. Since, overall, the leisure model is more appreciated than the cultural model, a strong trade-off seems to be driving the policy choices of the destination management.

\subsection{Choice probability of different scenarios}

As recalled in the introduction, our analysis follows two studies which, using the same methodology and a very similar questionnaire, were investigating summer tourists' preferences in Rimini (Brau et al. 2009) and residents of the city of Rimini (Figini et al. 2009). Given the similarity between the questionnaires, we were able to build a few scenarios based on some of the attributes in order to compare the probability that a representative off-season tourist in Rimini choose each scenario with the analogous probability for a resident and for a summer tourist. ${ }^{31}$ This simulation allows the identification of differences in the distribution of tourists and residents' preferences among alternative scenarios, and the identification of the preferred scenarios for residents and for different types of tourists. Moreover, it provides useful information for policy makers aiming at proposing social welfare enhancing tourism projects.

Table 12. Simulation of the distribution of choice probabilities in the case of four scenarios for residents, in-season and off-season tourists.

\begin{tabular}{|c|c|c|c|c|}
\hline Attributes & status quo & $\begin{array}{l}\text { Leisure } \\
\text { scenario }\end{array}$ & $\begin{array}{l}\text { cultural } \\
\text { scenario }\end{array}$ & $\begin{array}{l}\text { environmental } \\
\text { scenario }\end{array}$ \\
\hline environment impact & $\begin{array}{l}\text { high beach } \\
\text { impact and } \\
\text { motor. avenue }\end{array}$ & $\begin{array}{l}\text { high beach } \\
\text { impact and } \\
\text { ped. avenue }\end{array}$ & $\begin{array}{l}\text { high beach } \\
\text { impact and } \\
\text { ped. avenue }\end{array}$ & $\begin{array}{c}\text { low beach } \\
\text { impact and ped. } \\
\text { avenue }\end{array}$ \\
\hline Leisure \& culture & $\begin{array}{l}\text { No card and } \\
\text { only sea } \\
\text { holiday during } \\
\text { summer }\end{array}$ & $\begin{array}{l}\text { Leisure card } \\
\text { and only sea } \\
\text { holiday during } \\
\text { summer }\end{array}$ & $\begin{array}{l}\text { Cultural card, } \\
\text { (traditional) } \\
\text { museum } \\
\text { always open }\end{array}$ & $\begin{array}{l}\text { Cultural and } \\
\text { leisure cards, } \\
\text { ethnical } \\
\text { museum open } \\
\text { only during the } \\
\text { winter } \\
\end{array}$ \\
\hline shops open & $\begin{array}{c}\text { Close shops } \\
\text { and beach } \\
\text { during the } \\
\text { night }\end{array}$ & $\begin{array}{l}\text { Summer night } \\
\text { opening of the } \\
\text { beach and } \\
\text { shops open in } \\
\text { all seasons } \\
\text { and days and } \\
\text { during the } \\
\text { night }\end{array}$ & $\begin{array}{c}\text { Close shops } \\
\text { and beach } \\
\text { during the } \\
\text { night }\end{array}$ & $\begin{array}{c}\text { Close shops and } \\
\text { beach during the } \\
\text { night }\end{array}$ \\
\hline \multicolumn{5}{|l|}{ Choice probabilities } \\
\hline Off-season tourists & $17.52 \%$ & $29.15 \%$ & $26.25 \%$ & $27.07 \%$ \\
\hline In-season tourists & $9.52 \%$ & $41.12 \%$ & $25.96 \%$ & $23.40 \%$ \\
\hline Residents & $8.54 \%$ & $34.60 \%$ & $27.81 \%$ & $29.04 \%$ \\
\hline
\end{tabular}

31 It must be recalled that the twin studies on summer tourists and on residents slightly differed in the definition and in the levels of the cultural, leisure and monetary attributes. This might affect the estimated probabilities. 
The inspection of Table 12 shows that the status quo was always the worst scenario for all types of tourists and for residents. In-season and off-season tourists preferred the leisure scenario, but the cultural scenario was the second choice only for in-season tourists. On the contrary, the environmental scenario was the second choice for residents and off-season tourists, although the distribution of preferences among the three alternative scenarios to the status quo is quite uniform.

Again, policy makers seem to be facing a strong trade-off between the use of the territory and the demands and needs of "hosts" and "guests" of Rimini.

\section{Conclusions}

In this paper we attempted to check for any synergy and trade-off arising among different types of offseason tourists in a mass tourism destination. In the case of a mature destination such as Rimini, which recently made a great effort in diversifying mainly towards business and cultural tourism, this issue is crucial for both the tourism and the cultural policy of the territory. Who are off-season tourists in Rimini? What would they like in the cultural and leisure offer of the territory? What are the implications for the policy agenda of the destination management? These are the main questions we addressed with this work. Moreover, the structure of the investigation, very similar to twin studies carried out recently in Rimini on summer tourists (Brau et al., 2009) and on residents (Figini et al., 2009), allowed us to check for synergies and trade-offs among the population of residents and guests of Rimini.

The main results can be summed up as follows:

1. The socio-demographic analysis suggests that, off-season, it is possible to identify three main segments of tourists: business, leisure and cultural tourists. Business and leisure tourists share many features related to the use of the territory such that two homogeneous groups only can be identified by the latent-class analysis: the "leisure lovers" and the "culture lovers".

2. All these types of tourism ask for some improvements in the organization of the holiday in Rimini with respect to the status quo: they all would prefer to have a system of organized wellness, to walk on a seaside avenue closed to traffic, and "with a human face", to take advantage from an extended opening of shops.

3. Apart from these synergies, there are also important trade-offs, particularly between business and leisure tourism on one side (the "leisure lovers"), and cultural tourism on the other side (the "culture lovers"). Culture lovers ask for a system of discounts and facilities to visit the cultural offer of Rimini, while leisure lovers ask for a system of discounts and facilities for pubs, night clubs, restaurants. Culture lovers ask for a system of organized trips in the surroundings, which is not demanded by leisure lovers.

4. Although both business and cultural tourists show a weak willingness to increase the length of stay in the destination, only business tourists are the ones who are willing to spend one more full day in the city. Since this higher propensity to stay is directly linked with spending, and since business tourists are usually wealthier and with a softer budget constraint, from the destination point of view the first best would be to invest in improving the leisure features and the organization of the territory. This is also optimal if we consider the synergies that come out from the comparison with the demand of summer tourists. This is unsurprising, since Rimini is one of the main holiday and leisure areas in Italy, having been developed on the needs and the demand of summer tourists.

5. Is it efficient to invest in cultural activities and to promote cultural tourism in Rimini? From a tourism policy perspective, our impression is negative, since cultural tourists are not numerically important and since their demand partially contrasts with leisure lovers' demand. However, 
previous works find that summer tourists (Brau et al., 2009) and residents (Figini et al., 2009) ask for more cultural offer. Therefore, cultural tourism might play a fundamental role in the intermediate seasons, as a tool to de-seasonalize, to diversify the tourism investment, and also considering that Rimini has an important cultural heritage to value. To conclude, cultural tourism, although being definitely a "second best" for Rimini's tourism policy, does not have to be neglected.

6. From a cultural policy perspective, the promotion of cultural tourism involves a long term investment. A city like Rimini, which is internationally known as a summer and leisure destination, is not perceived as a cultural destination, regardless of the few exhibitions that can be organized during the year. To attach a brand of cultural city to Rimini, investments in cultural activities have to be repeated regularly and continuously (Candela et al., 2010). Moreover, in order to win the strong competition with other Italian cultural destinations, investments have to be directed towards contemporary art.

Apart from these conclusions, which are of local interest, we believe that our work deserves attention also from a more general perspective. Firstly, the methodology used (discrete choice models with latent-class analysis) can easily be applied to both other destinations and to other issues of cultural policy. Secondly, the policy implications of this type of analysis suggests that it would be wrong to consider tourism as a monolith, that the needs of different types of tourism might easily clash and that the policy of tourism development has to be handled with much care: not only a few territories can be successfully developed in tourism destinations, but also a few tourism destinations can successfully diversify towards cultural tourism. 


\section{References}

Akis S, Peristianis N, Warner J (1996) Residents' attitudes to tourism development: the case of Cyprus. Tourism Management 17:481-494.

Alberini A., Longo A. (2006) Combining the travel cost and contingent behavior methods to value cultural heritage sites: Evidence from Armenia. Journal of Cultural Economics 30:287-304.

Alberini A, Rosato, P Zanatta V (2005) Combining actual and contingent behaviour to estimate the value of sport fishing in the lagoon of Venice. Ecological Economics 61:530-41.

Apostolakis A, Shabbar J (2005) Stated preferences for two Cretan heritage attractions. Annals of Tourism Research 32:985-1005.

Bateman IJ, Carson RT, Day B, Hanemann M, Hanley N, Hett T, Jones-Lee M, Loomes G, Mourato S, Ozdemiroglu E, Pearce DW, Sugden R, Swanson J (2002) Economic valuation with stated preference techniques. Edward Elgar, Cheltenham UK.

Baum, T, Lundtrop S (2001) Seasonality in tourism, Pergamon, Oxford.

Ben-Akiva M, Lerman S (1985) Discrete choice analysis: theory and application to travel demand. MIT Press, Cambridge MA.

Bennett J, Blamey R (eds.) (2001) The choice modelling approach to environmental valuation. Edward Elgar, Cheltenham.

Brau R, Cao D (2008) Uncovering the macrostructure of tourists' preferences. A choice experiment analysis of tourism demand to Sardinia, in Brau R, Lanza A e Usai S (eds) Tourism and sustainable economic development: macroeconomic models and empirical methods, Edward Elgar, Chelthenam, UK.

Brau R, Scorcu AE, Vici L (2009) Assessing visitor satisfaction with tourism rejuvenation policies: the case of Rimini, Italy. Journal of Environmental Planning and Management 52(1).

Breffle W, Morey E (2000) Investigating preference heterogeneity in a repeated discrete-choice recreation demand model of Atlantic salmon fishing. Marine Resource Economics 15: 1-20

Candela G, Castellani M (2008) La stagionalità nel turismo e le politiche di destagionalizzazione, in L'Italia. Il

declino economico e la forza del turismo, ROMA, Marchesi Grafiche Editoriali, pp. 251 - 259.

Candela G, Cellini R, Scorcu AE (2003) Comportamenti d'impresa e informazione del consumatore: un'analisi empirica sui prezzi del pernottamento turistico, Politica economica 3:441-465.

Candela G, Giannerini S, Scorcu AE (2007) Le caratteristiche strutturali di una destinazione matura. Il caso di Rimini. Economia dei Servizi 1:123-46.

Candela G, Giannerini S, Di Lascio FML, Scorcu AE (2010) Turismo, Cultura e Territorio. Mimeo, University of Bologna.

Carson RT (2000) Contingent valuation: a user's guide. Environmental Sciences and Technology 34: 1413-1418

Caserta S, Russo AP (2002) More Means Worse: Asymmetric Information, Spatial Displacement and Sustainable Heritage Tourism. Journal of Cultural Economics, 26:245-260.

Crotts JC, Holland SM (1993) Objective indicators of the impact of rural tourism development in the state of Florida. Journal of Sustainable Tourism 1:112-120.

Crouch GI, Louviere JJ (2004) The determinants of convention site selection: a logistic choice model from experimental data. Journal of Travel Research 43:118-130.

Del Corpo B, Gasparino U, Bellini E, Malizia W (2008) Effects of Tourism upon the Economy of Small and Medium-Sized European Cities. Cultural Tourists and "the Others". FEEM Working Paper Series n. 44.2008.

Dwyer L, Forsyth P (1993) Assessing the benefits and costs of inbound tourism. Annals of Tourism Research 20:751-768.

Faulkner HW, Tideswell C (1997) A framework for monitoring community impacts of tourism. Journal of Sustainable Tourism 5:3-28.

Figini P, Troia T (2006) Le caratteristiche dei turisti a Rimini: un confronto tra due recenti indagini. SistemaEconomico 11:5-20.

Figini P, Castellani M, Vici L (2009) Estimating Tourist Externalities on Residents: a Choice Modeling Approach to the case of Rimini, in Advances in Tourism Economics. New Developments, BERLIN, Springer-Verlag, pp. 145164.

Freeman AM (1993) The measurement of environmental and resource values. Resources for the Future, Washington DC: $332-341$.

Hanley N, Wright R, Koop G (2002) Modelling recreation demand using choice experiments: climbing in Scotland. 
Environmental and Resource Economics 22:449-466.

Hanley N, Mourato S, Wright R (2001) Choice modelling: a superior alternative for environmental valuation. Journal of Economic Surveys 15:435-462.

Haralambopoulos N, Pizam A (1996) Perceived impacts of tourism: the case of Samoas. Annals of Tourism Research 23:503-526.

Hausman J, Wise D (1978) A conditional probit model for qualitative choice: discrete decisions recognizing interdependence and heterogeneous preferences. Econometrica 46:403-426.

Hensher D, Rose J, Greene W (2005) Applied choice analysis: a primer. Cambridge University Press, Cambridge

Huybers T (2005) Destination choice modelling: what's in a name? Tourism Economics 11:329-350.

Huybers T, Bennett J (2000) Impact of the environment on holiday destination choices of prospective UK tourists: implications for Tropical North Queensland. Tourism Economics 6:21-46.

Hylleberg S (1992) Modelling Seasonality, Oxford University Press, Oxford.

Koenig-Lewis N, Bishoff EE (2005) Seasonality research: the state of the art, International Journal of Tourism

Research, 7:201-219.

Lancaster K (1966) A new approach to consumer theory. Journal of Political Economy 74:132-157.

Lancaster K (1971) Consumer demand - a new approach. Columbia University Press, New York.

Lindberg K, Dellaert BGC, Rassing CR (1999) Resident trade-offs. A choice modeling approach. Annals of Tourism Research 26:554-69.

Lindberg K, Johnson R.L. (1997a) The economic values of tourism's social impacts. Annals of Tourism Research 24:90-116.

Lindberg K, Johnson RL (1997b) Modelling resident attitudes toward tourism. Annals of Tourism Research 24:402424.

Liu J, Sheldon P, Var T (1987) A cross-national approach to determining resident perceptions of the impact of tourism on the environment. Annals of Tourism Research 14:17-37.

Louviere JJ, Hensher DA, Swait JD (2000) Stated choice methods. Cambridge University Press, Cambridge.

Mazzanti M (2003) Discrete choice models and valuation experiments. Journal of Economic Studies 30:584-604.

McFadden D (1974) Conditional logit analysis of qualitative choice behaviour. In: Zarembka P (ed.) Frontiers in econometrics. Academic Press, New York, NY.

McFadden D (1984) Econometric analysis of qualitative response models. In: Griliches Z, Intriligator MD (eds.) Handbook of econometrics II. Elsevier Science, Amsterdam, pp 1395-1457.

Morey E, Rossmann KG, Chestnut LG, Ragland S (2002) Valuing reduced acid deposition injuries to cultural resources: marble monuments in Washington DC. In: Navrud S, Ready RC (eds) Applying environmental valuation techniques to historic buildings, monuments and artifacts. Edward Elgar, Cheltenham, UK.

Navrud S, Ready RC (2002) Valuing cultural heritage. Edward Elgar, Cheltenham, UK.

Papatheodorou A (2001) Why people travel to different places. Annals of Tourism Research 28:164-179.

Pearce DG (1989) Social impacts of tourism. In: Social Cultural and Environmental Impacts of Tourism, NSW Tourism Commission, Sydney, pp. 1-39.

Pizam A, Milman A (1984) The social impacts of tourism. UNEP Industry and Environment 7:11-14.

Poor PJ, Smith JM (2004). Travel cost analysis of a cultural heritage site: The case of historic St. Mary's City of Maryland. Journal of Cultural Economics, 28:217-229.

Pulido-Fernandez IJ, Sanchez-Rivero M (2010) Attitudes of the cultural tourists: a latent segmentation approach. Journal of Cultural Economics, 34:111-129.

Rosselló Nadal J, Riera Font A, Sansó Rosselló A (2004) The economic determinants of seasonal patterns, Annals of Tourism Research, 31:697-711.

Ryan C (1991) Recreational tourism: a social science perspective. Routledge, London.

Scorcu AE, Vici L (2008) Il turismo balneare a Rimini: scenario attuale e possibili evoluzioni nelle preferenze dei turisti. SistemaEconomico.

Thorsby D (2003) Determining the Value of Cultural Goods: How much (or How Little) Contingent Valuation Tell Us? Journal of Cultural Economics, 27:275-285.

Thurstone LL (1927) A Law of comparative judgement. Psychological Review 34:273-286.

Train K (2003) Discrete choice methods with simulation, Cambridge, Cambridge University Press.

Travis AS (1984) Social and cultural aspects of tourism. UNEP Industry and Environment 7:2-24.

Wall G, Mathieson A (2005) Tourism: Change, Impacts and Opportunities. Pearson Prentice Hall, Essex, UK.

Williams TA (1979) Impact of domestic tourism in host population: the evolution of a model. Tourist Recreation Research 4:15-21. 


\section{APPENDIX}

\section{Table A1: Factor extraction}

\begin{tabular}{|c|c|c|c|c|c|}
\hline Factor & । & Eigenvalue & Difference & Proportion & Cumulative \\
\hline Factor1 & 1 & 1.69965 & 0.42502 & 0.5711 & 0.5711 \\
\hline Factor 2 & 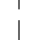 & 1.27463 & 0.63308 & 0.4283 & 0.9994 \\
\hline Factor3 & i & 0.64155 & 0.26449 & 0.2156 & 1.2149 \\
\hline Factor 4 & i & 0.37705 & 0.21037 & 0.1267 & 1.3416 \\
\hline Factor 5 & i & 0.16668 & 0.08076 & 0.0560 & 1.3976 \\
\hline Factor 6 & i & 0.08592 & 0.06266 & 0.0289 & 1.4265 \\
\hline Factor 7 & i & 0.02326 & 0.05578 & 0.0078 & 1.4343 \\
\hline Factor 8 & 1 & -0.03252 & 0.04027 & -0.0109 & 1.4234 \\
\hline Factorg & i & -0.07279 & 0.05092 & -0.0245 & 1.3989 \\
\hline Factor 10 & i & -0.12371 & 0.01067 & -0.0416 & 1.3574 \\
\hline Factor 11 & i & -0.13438 & 0.00751 & -0.0452 & 1.3122 \\
\hline Factor 12 & 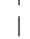 & -0.14189 & 0.08347 & -0.0477 & 1.2645 \\
\hline Factor 13 & | & -0.22536 & 0.04343 & -0.0757 & 1.1888 \\
\hline Factor 14 & i & -0.26879 & 0.02434 & -0.0903 & 1.0985 \\
\hline Factor 15 & | & -0.29313 & . & -0.0985 & 1.0000 \\
\hline
\end{tabular}

Figure A1: factor loadings

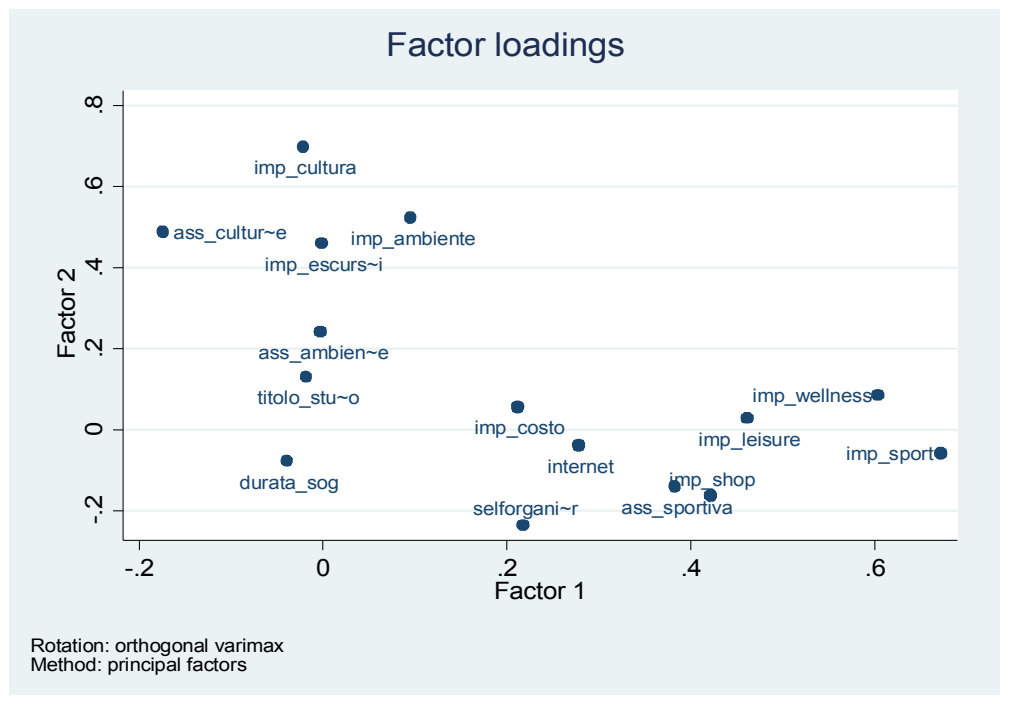

Table A2: Factor loadings (Varimax rotation)

\begin{tabular}{r|rr|rr} 
& \multicolumn{2}{|c}{ Rotated } & \multicolumn{2}{c}{ Unrotated } \\
Variable & Factor1 & Factor2 & Factorl & Factor2 \\
imp_escurs i & -0.0012 & $\mathbf{0 . 4 5 9 1}$ & -0.2589 & 0.3791 \\
imp_ambiente & 0.0957 & $\mathbf{0 . 5 2 3 0}$ & -0.2146 & 0.4864 \\
imp_wellness & $\mathbf{0 . 6 0 3 8}$ & 0.0846 & 0.4520 & 0.4092 \\
imp_sport & $\mathbf{0 . 6 7 2 3}$ & -0.0585 & 0.5891 & 0.3293 \\
imp_shop & $\mathbf{0 . 4 2 1 8}$ & -0.1630 & 0.4405 & 0.1021 \\
imp_costo & $\mathbf{0 . 2 1 2 2}$ & 0.0556 & 0.1443 & 0.1652 \\
imp_leisure & $\mathbf{0 . 4 6 1 5}$ & 0.0284 & 0.3658 & 0.2827 \\
imp_cultura & -0.0208 & $\mathbf{0 . 6 9 8 4}$ & -0.4096 & 0.5661 \\
ass_ambien e & -0.0025 & $\mathbf{0 . 2 4 1 1}$ & -0.1375 & 0.1980 \\
ass_cultur e & -0.1739 & $\mathbf{0 . 4 8 7 9}$ & -0.4179 & 0.3060 \\
ass_sportiva & $\mathbf{0 . 3 8 2 6}$ & -0.1397 & 0.3950 & 0.0993 \\
selforgani r & $\mathbf{0 . 2 1 7 9}$ & $-\mathbf{0 . 2 3 5 4}$ & 0.3125 & -0.0723 \\
durata_sog & -0.0387 & -0.0771 & 0.0113 & -0.0855 \\
titolo_stu o & -0.0179 & $\mathbf{0 . 1 3 0 6}$ & -0.0882 & 0.0980 \\
internet & $\mathbf{0 . 2 7 8 5}$ & -0.0388 & 0.2522 & 0.1244
\end{tabular}

